University of Montana

ScholarWorks at University of Montana

Numerical Terradynamic Simulation Group

Publications

Numerical Terradynamic Simulation Group

2-1985

\title{
Water and Nutrient Outflow From Contrasting Lodgepole Pine Forests in Wyoming
}

D. H. Knight

T. H. Fahey

Steven W. Running

University of Montana - Missoula

Follow this and additional works at: https://scholarworks.umt.edu/ntsg_pubs

Let us know how access to this document benefits you.

\section{Recommended Citation}

Knight, D. H., Fahey, T. J. and Running, S. W. (1985), Water and Nutrient Outflow From Contrasting Lodgepole Pine Forests in Wyoming. Ecological Monographs, 55: 29-48. doi:10.2307/1942524

This Article is brought to you for free and open access by the Numerical Terradynamic Simulation Group at ScholarWorks at University of Montana. It has been accepted for inclusion in Numerical Terradynamic Simulation Group Publications by an authorized administrator of ScholarWorks at University of Montana. For more information, please contact scholarworks@mso.umt.edu. 


\title{
WATER AND NUTRIENT OUTFLOW FROM CONTRASTING LODGEPOLE PINE FORESTS IN WYOMING ${ }^{1}$
}

\author{
DenNis H. KNIGHT and Timothy J. FaheY ${ }^{2}$ \\ Department of Botany, Ciniversity of Wyoming, Laramie, Wyoming 82071 USA \\ AND \\ STEVEN W. RUNNING \\ School of Forestry, Lniversity of Montana, Missoula, Montana 59812 USA
}

\begin{abstract}
Factors affecting water and nutrient outflow beyond the rooting zone were studied during a 3-yr period, using data from eight contrasting stands of lodgepole pine (Pinus contorta ssp. latifolia) forest in southeastern Wyoming and the output of a hydrologic simulation model (H2OTRANS) based on tree physiology. Nutrient outflow during a specific time period was estimated by multiplying simulated water outflow times element concentrations in the soil solution, the latter determined from samples collected periodically near the bottom of the rooting zone.

Estimates of actual evapotranspiration ( $E T)$ for the period from early spring to late fall ranged from 21 to $53 \mathrm{~cm}$, which was $33-95 \%(\bar{x}=73 \%)$ of total annual precipitation. For all stands and years, transpiration accounted for $50-61 \%$ of $E T$, and $9-44 \%$ of the transpiration occurred during the spring drainage period (vernal transpiration, VT). Estimated VT and outflow varied considerably among the stands, with VT accounting for $4-20 \%$ of the snow water. Outflow occurred only during the snow melt period and accounted for $0-80 \%$ of the snow water. Snow water equivalent varied annually by $300 \%$ or more. Nutrient outflow from the different stands also varied greatly. Ratios between simulated annual outflow and atmospheric inputs (bulk precipitation) were consistently $>1.0$ for $\mathrm{Ca}, \mathrm{Na}$, and $\mathrm{Mg}$; were consistently $<1.0$ for $\mathrm{N}$; and ranged from 0.3 to 2.0 for $\mathrm{P}$ and from 0.2 to 3.3 for $\mathrm{K}$. Much of the variability in water and nutrient outflow can be attributed to the degree of biotic control, with water outflow affected by a different combination of factors than nutrient outflow. H2OTRANS was used to simulate the effects on outflow of different snow water equivalents and different total leaf areas. One result of the simulations was that nitrogen appears to be retained even at the highest levels of water outflow. Another was that increases in water outflow following reduction in leaf area were proportional to the leaf area removed.

The results indicate that stands differing in site or habitat type experience different rates of water and element losses at different times during the snow melt season, and contribute differentially to streamwater quality and hydrograph shape. Factors affecting outflow are discussed in the context of successional trends, common perturbations including timber harvest, and hypotheses pertaining to nutrient conservation in terrestrial ecosystems. Nutrient retention in the snow-dominated lodgepole pine ecosystem appears to be primarily dependent on evergreen leaf area, duration of the VT period, and high carbon/nutrient ratios of the forest floor. Net losses of limiting nutrients probably occur primarily in pulses after abiotic perturbations such as fire.
\end{abstract}

Key words: computer simulation; evapotranspiration; forest biomass; forest hydrology; habitat types; immobilization; leaf area; nitrogen; nutrient input; nutrient outflow: Pinus contorta; Rocky Mountains; transpiration; Wyoming.

\section{INTRODUCTION}

Many studies on water and nutrient movement in terrestrial ecosystems have focused on outflow, partly because losses can be accelerated by some land uses but also because there are various popular hypotheses concerning the balance between nutrient input and output. For example, nutrient balance has been related to such ecosystem characteristics as successional status and diversity (Odum 1969), transpiration (Bormann et al. 1969), soil respiration and rainfall patterns (McColl 1973), biomass increment (Vitousek and Reiners 1975), microbial uptake (Stark 1972), and certain element-

\footnotetext{
' Manuscript received 21 March 1983; revised 3 January 1984; accepted 4 January 1984.

- Present address: Department of Natural Resources. Cornell University, Ithaca, New York 14853 USA.
}

specific processes such as nitrification (Likens et al. 1977). Each hypothesis appears to be correct in certain situations but, as with any ecosystem phenomenon, water and nutrient losses are influenced by many factors that vary through time and space. Our objective was to analyze the factors affecting water and nutrient outflow from small, relatively homogeneous stands of Rocky Mountain forest dominated by lodgepole pine (Pinus contorta ssp. latifolia [Engelm. ex Wats.] Critchfield). The results are discussed in the context of forest management and current hypotheses on water and nutrient fluxes.

Factors affecting the input-output balance of water and nutrients have often been studied using the smallwatershed approach. This approach has been extremely useful where impervious substrata exist. However, it is often more difficult to examine in detail the 
factors regulating nutrient loss from specific areas within watersheds because streams integrate outflow from the patches and gradients that invariably exist (Rutter 1968). Hydrologists, recognizing that runoff from two equal portions of a watershed may be quite different, have developed the concept of contributing area or variable source area (Rawitz et al. 1970). Furthermore, the elemental composition of stream water is affected by stream bank erosion, soil characteristics below the root zone, bedrock composition, and stream organisms, in addition to nutrient loss from the terrestrial ecosystem under study.

We chose to study stands instead of watersheds because of our interest in examining the effects on outflow of varying edaphic and vegetative conditions. The principal problem encountered with the stand approach is accurate estimation of water and nutrient outflow, even from stands that are small and homogeneous. Our approach to this problem has been to develop a stand-level simulation model (H2OTRANS) that calculates water outflow as the difference between hydrologic inputs and the sum of evapotranspiration and storage. The model integrates the effects of air temperature, atmospheric humidity, solar radiation, precipitation, soil storage capacity, and stand leaf area. In this paper we describe the development and validation of this model, and the results we obtained by using the model to examine water and nutrient outflow from lodgepole pine forest stands with contrasting characteristics. Nutrient outflow was calculated as the product of water outflow and nutrient concentrations in the soil solution near the bottom of the rooting zone.

Lodgepole pine forests in the Rocky Mountains have several characteristics that were relevant to the planning of our research. First, snow melt and early spring rain are normally the only sources of water adequate to cause nutrient leaching beyond the rooting zone (Reynolds and Knight 1973). Thus, outflow usually occurs only once during the year, in what can be referred to as the snow melt or spring flush period. Under these conditions, nutrient loss is partly dependent on the quantity of nutrients available for outflow at the end of the winter. Organic matter is mineralized under the snowpack (Fahey 1983), and large amounts of nutrients are potentially available for leaching during the spring flush period, a time when root uptake is probably slow.

Another feature is the great variability in leaf area, stand structure, and soil storage capacity. Tree density may vary from $<300$ to $\geq 15000$ trees/ha, and the range in the leaf area index of mature stands is as great as from 4 to 14, or greater (Moir and Francis 1972). We have observed lodgepole pine forests on both deep glacial till soils $(>3 \mathrm{~m})$ and coarse, shallow soils derived from a granitic substrate $(<0.5 \mathrm{~m})$. Although most of the root system occurs in the upper $0.4 \mathrm{~m}$ (Pearson 1982), tap roots extend down to $2 \mathrm{~m}$ or more where bedrock permits, and the soil profile dries steadi- ly during the summer to this depth or below (Dahms 1971, Johnston and Doty 1972, Johnston 1975). On many sites soil water is depleted in late summer and trees come under water stress (Fetcher 1976), with the soil remaining dry and usually unfrozen during the winter. Modelling the restriction of transpiration by stomatal control following water stress development has been one of the challenges in developing H2OTRANS.

A third feature of the lodgepole pine ecosystem is the capacity for vernal transpiration (VT), i.e., transpiration during the snow melt period and immediately after, while deep drainage continues. Several studies have shown that sapwood recharge and transpiration occur during this time (Swanson 1967, Owston et al. 1972, Fahey 1979). Our research was designed, in part, to estimate (1) the proportion of the snowpack that can be transpired during the snow melt period, thereby reducing outflow; and (2) the conditions of snowfall, water storage capacity, and VT that reduce the outflow of water and nutrients to zero. Outflow may be an annual event in some stands but less regular in others.

\section{Study Area A.vd Methods \\ Description of study area}

Eight stands of lodgepole pine forest in the Medicine Bow Mountains of southeastem Wyoming were selected to represent the variety of stand structure and soil characteristics in the area. Data on water, nutrients, climatic characteristics, and biomass in these stands were collected during the period 1978-1982. Each stand was $\approx 1-3$ ha in area and relatively homogeneous in forest and soil structure. Six of the eight stands were virgin forest. The stands were located at elevations of 2800-3050 m, and represented four ages $(17,70,110$, $240 \mathrm{yr}$ ); tree density was 375-14640 stems/ha, and leaf area indices ( $\mathrm{LAI}$, all surfaces) ranged from 1 to 10. Understory vegetation was sparse in all stands except French Creek and Rock Creek (Table 1). In two instances the stands occurred in adjacent pairs on the same soil type: a 20-yr-old stand (Chimney Park I) that had originated after a clearcut, next to a 110 -yr-old uncut forest (Chimney Park II); and two adjacent 110 yr-old stands, one very dense (Dry Park II, 14640 trees/ha) and the other more open (Dry Park I, 2217 trees/ha). These pairs provided the opportunity to study the effect of stand structure on water and nutrient outflow without the variability introduced by different climatic or soil characteristics.

The soils of the eight study areas were variable (Table 2); both Inceptisols (Lithic Cryochrepts) and Alfisols (Typic Cryoboralfs) were observed. Soils at three of the sites (Nash Fork, Rock Creek, and French Creek) were derived from Quatemary glacial alluvium, whereas soils at the other sites were derived from either Precambrian granite (Albany), coarse outwash (Dry Park), or schist (Chimney Park). Soil depth ranged from $\approx 0.5 \mathrm{~m}$ on 
TABLE 1. Vegetation characteristics of the eight study areas in the Medicine Bow Mountains, Wyoming.

\begin{tabular}{|c|c|c|c|c|c|c|c|c|}
\hline \multirow[b]{2}{*}{ Stand feature } & \multicolumn{2}{|c|}{$\begin{array}{l}\text { Two adjacent } \\
\text { stands at } \\
\text { Chimney Park }\end{array}$} & \multicolumn{2}{|c|}{$\begin{array}{l}\text { Two adjacent } \\
\text { stands at } \\
\text { Dry Park }\end{array}$} & \multirow[b]{2}{*}{ Albany } & \multirow{2}{*}{$\begin{array}{l}\text { Nash } \\
\text { Fork }\end{array}$} & \multirow{2}{*}{$\begin{array}{l}\text { French } \\
\text { Creek }\end{array}$} & \multirow{2}{*}{$\begin{array}{l}\text { Rock } \\
\text { Creek }\end{array}$} \\
\hline & $I$ & II & I & II & & & & \\
\hline $\begin{array}{l}\text { Age (yr) } \\
\text { Tree density (stems/ha) } \\
\text { Height of canopy top }(\mathrm{m})^{*}\end{array}$ & $\begin{array}{c}17 \\
4518 \\
2.3\end{array}$ & $\begin{array}{r}110 \\
9700 \\
6.1\end{array}$ & $\begin{array}{r}110 \\
2217 \\
11.9\end{array}$ & $\begin{array}{c}110 \\
14640 \\
5.6\end{array}$ & $\begin{array}{l}\text { Uneven } \\
1920 \\
7.3\end{array}$ & $\begin{array}{c}110 \\
1850 \\
10.4\end{array}$ & $\begin{array}{l}240 \\
420 \\
15.1\end{array}$ & $\begin{array}{r}75 \\
1280 \\
8.6\end{array}$ \\
\hline $\begin{array}{l}\text { Tree basal area }\left(\mathrm{m}^{2} / \mathrm{ha}\right) \\
\text { Tree sapwood basal area }\left(\mathrm{m}^{2} / \mathrm{ha}\right)^{*} \\
\text { Tree sapwood volume }\left(\mathrm{m}^{3} / \mathrm{ha}\right)^{*}\end{array}$ & $\begin{array}{l}1 \\
1 \\
5.0\end{array}$ & $\begin{array}{l}55 \\
25 \\
94.5\end{array}$ & $\begin{array}{l}42 \\
25 \\
161.4\end{array}$ & $\begin{array}{l}50 \\
36 \\
113.9\end{array}$ & $\begin{array}{l}20 \\
14 \\
67.3\end{array}$ & $\begin{array}{l}64 \\
28 \\
187.7\end{array}$ & $\begin{array}{l}37 \\
12 \\
100.5\end{array}$ & $\begin{array}{l}26 \\
18 \\
115.2\end{array}$ \\
\hline $\begin{array}{l}\text { Tree biomass }(\mathrm{Mg} / \mathrm{ha}) \\
\text { Leaf } \\
\text { Total } \\
\text { Understory cover }(\%)\end{array}$ & $\begin{array}{l}1.5 \\
4.8 \\
5\end{array}$ & $\begin{array}{l}10.0 \\
170.0 \\
2\end{array}$ & $\begin{array}{r}9.7 \\
171.7\end{array}$ & $\begin{array}{r}8.4 \\
144.9 \\
1\end{array}$ & $\begin{array}{r}5.6 \\
76.1 \\
2\end{array}$ & $\begin{array}{l}11.4 \\
174.8 \\
15\end{array}$ & $\begin{array}{r}6.9 \\
174.7 \\
35\end{array}$ & $\begin{array}{l}12.2 \\
98.4 \\
32\end{array}$ \\
\hline $\begin{array}{l}\text { Leaf area : mass ratio }\left(\mathrm{cm}^{2} / \mathrm{g}\right) \dagger \\
\text { Leaf area index }\left(\mathrm{m}^{2} / \mathrm{m}^{2}\right)^{*}\end{array}$ & $\begin{array}{r}89.1 \\
1.3\end{array}$ & $\begin{array}{r}87.7 \\
8.8\end{array}$ & $\begin{array}{r}74.9 \\
7.3\end{array}$ & $\begin{array}{r}84.3 \\
7.1\end{array}$ & $\begin{array}{r}69.6 \\
3.9\end{array}$ & $\begin{array}{r}87.2 \\
9.9\end{array}$ & $\begin{array}{r}64.5 \\
4.5\end{array}$ & $\begin{array}{r}73.2 \\
9.0\end{array}$ \\
\hline
\end{tabular}

* Stand parameters for H20TRANS; see Study Area and Methods: Estimating Outflow.

† Kaufmann and Troendle (1981) calculated a value of 95.2 for Pinus contorta in Colorado.

the granite at Albany to $>2 \mathrm{~m}$ on the glacial alluvium, and maximum water storage capacity in the soils ranged from 6 to $22 \mathrm{~cm}$ (Table 3).

\section{Climatic characteristics}

The climate throughout the Medicine Bow Mountains is characterized by long, cold winters and short, cool summers, with mean daytime temperature and relative humidity in July of $\approx 20^{\circ} \mathrm{C}$ and $\approx 25 \%$, respectively. Snow normally begins to accumulate by the end of October, and usually the stands are not snowfree until early June or later (depending on the amount of snow, elevation, LAI, and aspect). Total precipitation in the stands ranged from 41 to $90 \mathrm{~cm}$ with $\approx 68 \%$ of the annual precipitation coming as snow (Table 3 ).

An instrument tower was placed in each stand. It supported a ventilated shelter (painted white) contain- ing a hygrothermograph mounted at mid-canopy. An actinograph and standard precipitation gauge were mounted either at the top of the tower above the canopy or on a small platform in a nearby, unobstructed opening. Precipitation was measured within $24 \mathrm{~h}$ after each rainfall event $(>0.2 \mathrm{~cm}$ ), and the hygrothermographs were serviced and calibrated weekly from late April or early May until mid-October. Temperature and relative humidity readings of the hygrothermograph were rarely in error by more than $2^{\circ}$ and $5 \%$, respectively. The actinographs were calibrated once at the beginning of each field season. Data gaps caused by pen skips or clock malfunction were filled with data from the nearest stand (usually $2-5 \mathrm{~km}$ distant). Temperature, humidity, and solar radiation data were summarized as mean hourly values, and rainfall was recorded as the sum occurring on a particular Julian date.

TABLE 2. Some soil characteristics of the eight study areas in the Medicine Bow Mountains, Wyoming.

\begin{tabular}{|c|c|c|c|c|c|c|}
\hline Soil feature & $\begin{array}{l}\text { Two adjacent } \\
\text { stands at } \\
\text { Chimney Park }\end{array}$ & $\begin{array}{c}\text { Two adjacent } \\
\text { stands at } \\
\text { Dry Park }\end{array}$ & Albany & Nash Fork & French Creek & Rock Creek \\
\hline $\begin{array}{l}\text { Depth }(\mathrm{m}) \\
\text { pH at } 0-15 \mathrm{~cm}^{*}\end{array}$ & $\begin{array}{l}1-2 \\
5.7 \\
6.3\end{array}$ & $\begin{array}{r}>2 \\
5.5 \\
8.3\end{array}$ & $\begin{array}{l}0.5 \\
5.5 \\
5.8\end{array}$ & $\begin{array}{r}>2 \\
5.5 \\
7.4\end{array}$ & $\begin{array}{r}>2 \\
5.3 \\
9.3\end{array}$ & $\begin{array}{l}>2 \\
5.0 \\
7.0\end{array}$ \\
\hline $\begin{array}{l}\text { Organic matter at } \\
0-15 \mathrm{~cm}(\% \text { dry } \\
\text { mass }) \dagger\end{array}$ & & & & & & \\
\hline $\begin{array}{l}\text { Bulk density at } \\
0-30 \mathrm{~cm}(\mathrm{~g} / \\
\left.\mathrm{cm}^{3}\right) \ddagger\end{array}$ & 1.53 & 1.47 & 1.32 & 1.40 & 1.22 & 1.05 \\
\hline $\begin{array}{l}\text { Geologic sub- } \\
\text { strate }\end{array}$ & schist & $\begin{array}{l}\text { glacial allu- } \\
\text { vium }\end{array}$ & granite & glacial till & glacial till & glacial till \\
\hline Soil type & $\begin{array}{l}\text { Inceptisol } \\
\text { (lithic cry- } \\
\text { ochrept, } \\
\text { coarse loamy) }\end{array}$ & $\begin{array}{l}\text { Alfisol (typic } \\
\text { cryoboralf, } \\
\text { loamy skele- } \\
\text { tal) }\end{array}$ & $\begin{array}{l}\text { Inceptisol } \\
\text { (lithic cry- } \\
\text { ochrept, loamy } \\
\text { skeletal) }\end{array}$ & $\begin{array}{l}\text { Alfisol (typic } \\
\text { cryoboralf, } \\
\text { fine loamy) }\end{array}$ & $\begin{array}{l}\text { Alfisol (typic } \\
\text { cryoboralf, } \\
\text { loamy skele- } \\
\text { tal) }\end{array}$ & $\begin{array}{l}\text { Inceptisol } \\
\text { (typic cry- } \\
\text { ochrept, fine } \\
\text { loamy) }\end{array}$ \\
\hline
\end{tabular}

* Measured as a 1:I soil water suspension (Jackson 1958).

$\dagger$ Dry ashing at $600^{\circ} \mathrm{C}$ (Jackson 1958 ).

$\ddagger$ The mean of five pits. using the excavation method (Blake 1965). 
TABLE 3. Elevation and hydrologic characteristics of the eight study areas in the Medicine Bow Mountains, Wyoming.

\begin{tabular}{|c|c|c|c|c|c|c|c|c|}
\hline \multirow[b]{2}{*}{ Stand feature } & \multicolumn{2}{|c|}{$\begin{array}{l}\text { Two adjacent } \\
\text { stands at } \\
\text { Chimney Park }\end{array}$} & \multicolumn{2}{|c|}{$\begin{array}{l}\text { Two adjacent } \\
\text { stands at } \\
\text { Dry Park }\end{array}$} & \multirow[b]{2}{*}{ Albany } & \multirow{2}{*}{$\begin{array}{l}\text { Nash } \\
\text { Fork }\end{array}$} & \multirow{2}{*}{$\begin{array}{l}\text { French } \\
\text { Creek }\end{array}$} & \multirow{2}{*}{$\begin{array}{l}\text { Rock } \\
\text { Creek }\end{array}$} \\
\hline & 1 & II & $I$ & II & & & & \\
\hline Elevation $(\mathrm{m})$ & 2730 & 2730 & 2750 & 2750 & 2750 & 2900 & 2970 & 3050 \\
\hline $\begin{array}{l}\text { Snow melt coefficient }\left(\mathrm{cm} /{ }^{\circ} \mathrm{C} \text { ) }\right. \\
\text { Maximum rate of water flux from }\end{array}$ & 0.0100 & - & 0.0100 & 0.0070 & 0.0110 & 0.0054 & 0.0110 & 0.0096 \\
\hline & $-*$ & - & 0.100 & 0.100 & 0.100 & 0.100 & 0.100 & 0.010 \\
\hline zone $B$ to outflow $(\mathrm{cm} / \mathrm{h})$ & - & - & 0.017 & 0.021 & 0.100 & 0.100 & 0.200 & 0.010 \\
\hline \multicolumn{9}{|l|}{ Maximum available storage $(\mathrm{cm})$} \\
\hline $\begin{array}{l}\text { Forest floor } \\
\text { Root zone A } \\
\text { Root zone B } \\
\text { Sapwood } \\
\text { Foliage }\end{array}$ & $\begin{array}{l}0.2 \\
\overline{-} \\
0.03 \\
0.002\end{array}$ & $\begin{array}{l}0.4 \\
\overline{\bar{a}} \\
0 . \overline{9} \\
0.06\end{array}$ & $\begin{array}{c}0.3 \\
7.5 \\
14.0 \\
0.9 \\
0.07\end{array}$ & $\begin{array}{r}0.4 \\
7.8 \\
12.0 \\
0.7 \\
0.05\end{array}$ & $\begin{array}{l}0.2 \\
4.0 \\
1.6 \\
0.4 \\
0.03\end{array}$ & $\begin{array}{l}0.5 \\
5.3 \\
11.0 \\
1.1 \\
0.08\end{array}$ & $\begin{array}{c}0.5 \\
5.0 \\
16.0 \\
0.6 \\
0.04\end{array}$ & $\begin{array}{l}0.3 \\
3.7 \\
7.9 \\
0.7 \\
0.05\end{array}$ \\
\hline \multicolumn{9}{|l|}{$\begin{array}{l}\text { Maximum snow water equivalent } \\
\text { (cm), with total annual precipita- } \\
\text { tion }(\mathrm{cm}) \text { in parentheses } \dagger\end{array}$} \\
\hline $\begin{array}{l}1977 \\
1978 \\
1979 \\
1980 \\
1981\end{array}$ & $\begin{array}{l}\overline{-} \\
25(41) \\
32(58) \\
10(-)\end{array}$ & $\begin{array}{l}\overline{-} \\
2 \overline{2}(43) \\
30(56) \\
10(-)\end{array}$ & $\begin{array}{l}18(-) \\
23(-) \\
35(63) \\
34(60) \\
14(43)\end{array}$ & $\begin{array}{l}20(-) \\
24(-) \\
42(70) \\
37(63) \\
14(43)\end{array}$ & $\begin{array}{l}- \\
\overline{-} \\
40(72) \\
19(63) \\
19(45)\end{array}$ & $\begin{array}{l}42(- \\
47(71) \\
39(66) \\
28(56)\end{array}$ & $\begin{array}{l}89(- \\
49(79) \\
49(80) \\
31(61)\end{array}$ & $\begin{array}{l}33(-) \\
- \\
72(90) \\
55(75) \\
-\end{array}$ \\
\hline
\end{tabular}

- indicates no data.

$\dagger$ Total precipitation estimates do not include snowfall intercepted or sublimated in the forest canopy.

Soil temperature at $0.25 \mathrm{~m}$ was measured periodically with a bimetallic probe to determine seasonal trends.

\section{Biomass distribution and LAI}

The biomass values in Table 1 were estimated using standard dimension analysis techniques on a total of 80 trees harvested from the various stands (Pearson et al. 1984). Foliage, branch, bole, and root masses were estimated separately. Sapwood volume was calculated from measurements of stem height, basal area, sapwood width (from inside bark) and heartwood diameter. Leaf area for a stand was calculated by multiplying total leaf mass by the fresh leaf surface area per gram of dry mass, which in turn was determined separately for each stand as follows. Ten samples, each of 50 fresh needles, were collected randomly from each stand and measured for length of the green portion (to nearest millimetre) and mid-length diameter (to nearest 0.1 $\mathrm{mm}$ with a vernier caliper). The fascicles were then dried for $48 \mathrm{~h}$ at $100^{\circ}$, cooled in a desiccating cabinet, and weighed to the nearest $0.1 \mathrm{mg}$. Leaf area per needle was calculated using the formula, Area $=(\pi d l+$ $2 d l) \times 0.94$, where $d$ is the needle diameter and $l$ is the length. The formula is that for a split cylinder, with a correction factor of 0.94 to account for needle taper (Waggoner and Turner 1971). The values ranged from 64.5 to $89.1 \mathrm{~cm}^{2} / \mathrm{g}$ (Table 1 ).

For root biomass, two to five trenches each 4-5 m long were dug by backhoe as deeply as possible (usually down to $2 \mathrm{~m}$ ) in each stand. The distribution and mass of lateral root biomass was then estimated using a planar intersect technique (Pearson et al. 1984); root crown and fine root mass were determined by excavation. The trenches were also used for determining soil characteristics. Forest floor biomass was estimated as the combined mass of the 01 and 02 layers (Fahey 1983).

\section{Snow water equivalent and water storage capacity}

Water equivalent of the snowpack (in centimetres) was monitored in each stand at 5-10 d intervals, using a calibrated Montrose snow sampler. Data collection began in March or April, prior to the initiation of snow melt, and continued until the snow disappeared. At least 20 snow cores were weighed on each sampling date, a sample size which usually provided a standard error of $<10 \%$ of the mean. The data were used to estimate maximum water equivalent in the snowpack and the rate of snow melt for each stand during the 3-yr study period. Snowfall that occurred during the snow melt period but after the maximum snowpack measurement was treated as a rainfall event (vernal precipitation, VP). No attempt was made to measure snow interception or sublimation in the forest canopy, so our values for total annual precipitation are minimum estimates. We assumed no water input by lateral flow or by capillarity from below the rooting zone, but this was subsequently found not to be true for three stands. Because we did not measure this input, hydrologic budgets for these stands could not be calculated.

Water storage capacity was measured in six compartments: leaves, sapwood, forest floor, canopy, surface soil $(0-0.4 \mathrm{~m})$, and subsurface soil $(>0.4 \mathrm{~m}$, down to $2.0 \mathrm{~m}$ wherever possible). Leaf, sapwood, and forest 
floor storage were estimated as the difference between the amount of water in each when maximally hydrated, shortly after snow melt, and the amount after an extended period with no rain. Throughfall was estimated using 25 randomly located collectors in four of the stands; canopy storage was calculated as the difference between throughfall and total rainfall, expressed for modelling purposes as centimetres of water per square centimetre of leaf area. Stemflow in our stands was observed very infrequently and therefore was not measured.

Aluminum tubes were installed in the soil (8-12 tubes per stand) to allow water measurement by neutron thermalization (Gardner 1965) with a Campbell-Pacific neutron probe. Holes were drilled with a pneumatic rock drill using a $6.4-\mathrm{cm}$ bit, after which the tubes were tamped firmly into place using soil from a nearby trench. Probe readings were taken at $20-\mathrm{cm}$ depth intervals. Using the manufacturer's calibration curve, volumetric soil water content was estimated for the surface soil and subsoil at the time of saturation (within $48 \mathrm{~h}$ after the snow-free date) and then biweekly until late September or early October, when the soil profile was driest. Storage capacity was calculated as the difference between the maximum amount estimated in the spring and the lowest value observed in the fall. No field calibration of the neutron probe was attempted, partly because no other field method is as precise as neutron thermalization (van Bavel 1958), but also because our primary interest was in the change in water volume through time rather than in the actual amount of water in the soil at any particular time. We assumed that soil organic matter remained constant, so that the change in hydrogen content was due solely to a change in soil water. Soil water values (e.g., Fig. 4) were calculated as the product of maximum storage capacity, estimated as described above, and the percent of the maximum probe reading at the time of interest.

\section{Collection and chemical analysis of precipitation and soil leachate}

Samples of the accumulated snowpack were collected from large forest openings adjacent to four of the stands prior to the onset of snow melt in March of 1979 and 1980. Snow samples were collected directly into $0.5-\mathrm{L}$ polyethylene bottles from three depths at 10 randomly selected points at each site. Bulk precipitation in the spring, summer, and fall was collected after most measurable rainfall events ( 97 collections in $2 \mathrm{yr}$ ), using polyethylene funnels attached to $0.5-\mathrm{L}$ plastic bottles and placed above the canopy or in unobstructed openings at five sites. A glass fiber plug was inserted in the funnel to intercept large particulate matter, but dry atmospheric deposition contributed to the element concentrations measured in the samples. Volume-weighted mean element concentrations were calculated by dividing element fluxes in bulk rain by the total rainfall volume.
Samples of outflow water were obtained using 6-8 porous-cup soil water collectors (Parizek and Lane 1970) located near the bottom of the rooting zone (near bedrock or at $1.5-2.0 \mathrm{~m}$ depth). As with the neutron probe access tubes, holes were made with a pneumatic rock drill. The ceramic cups were embedded in fine silica powder at the bottom of each hole, and sifted soil from approximately the same depth was tamped firmly around the tube up to the surface. The collectors were evacuated to a tension of $0.012 \mathrm{MPa}$ shortly after the initiation of snow melt, and samples were collected at $2-5 \mathrm{~d}$ intervals until $\approx 2 \mathrm{wk}$ after snow disappearance. Although the water samples often remained in the collectors for several days, the water and soil temperatures during this period were only $1^{\circ}-2^{\circ}$. Concentrations of certain elements in the soil water could have been altered by collector installation, but we assumed that the collectors equilibrated with the surrounding soil after 1 yr because in most cases the 2nd-yr data were not significantly different from the 3 rd-yr data. In this paper we use only data obtained during the 3rd yr (1982).

Collecting soil water samples through porous cups, or any other device, is problematical because it cannot be known with certainty whether the sample represents capillary water or macropore water (Shaffer et al. 1979). This problem may be negligible in stands such as ours, where soil saturation may allow micropore and macropore water to reach chemical equilibrium. In any case, additional investigation on the occurrence and chemistry of macropore (unsaturated) flow is needed.

All liquid water samples were returned to the laboratory on the day of collection and filtered through glass fiber filters. Samples were stored at $\approx 2^{\circ}$ for a maximum of $72 \mathrm{~h}$ (usually $<36 \mathrm{~h}$ ) before being analyzed for ortho-P, $\mathrm{NO}_{2}+\mathrm{NO}_{3}$, and $\mathrm{NH}_{4}$ using standard methods for a continuous flow autoanalyzer (Scientific Instruments, Pleasantville, New York). To avoid hydrolysis of organic N (White and Gosz 1981), color development in the $\mathrm{NH}_{4}$ analysis was carried out at $37^{\circ}$, buffered at $\mathrm{pH}$ between 11 and 12 . Samples were stored for up to 2 wk at $2^{\circ}$ before being analyzed for $\mathrm{Ca}, \mathrm{Mg}, \mathrm{K}$, and $\mathrm{Na}$ by atomic absorption spectrophotometry (Perkin-Elmer 560); 1\% lanthanum was added in the $\mathrm{Ca}$ and $\mathrm{Mg}$ analyses to limit interference. Following no more than $6 \mathrm{wk}$ storage at $2^{\circ}$, total $P$ and total Kjeldahl nitrogen (TKN) were determined by colorimetric methods on the autoanalyzer after standard digestions (Golterman et al. 1978). Total N values reported in this study represent the sum of TKN and $\mathrm{NO}_{2}+\mathrm{NO}_{3}$. Following thawing and filtering, snow water samples were analyzed by the same methods.

\section{Estimating outflow by computer simulation}

Soil water collectors can be used to obtain samples of outflow water, but they do not provide an estimate of outflow quantity. Because there are no reliable methods for measuring this parameter, most studies of out- 


\section{HZOTRANS}

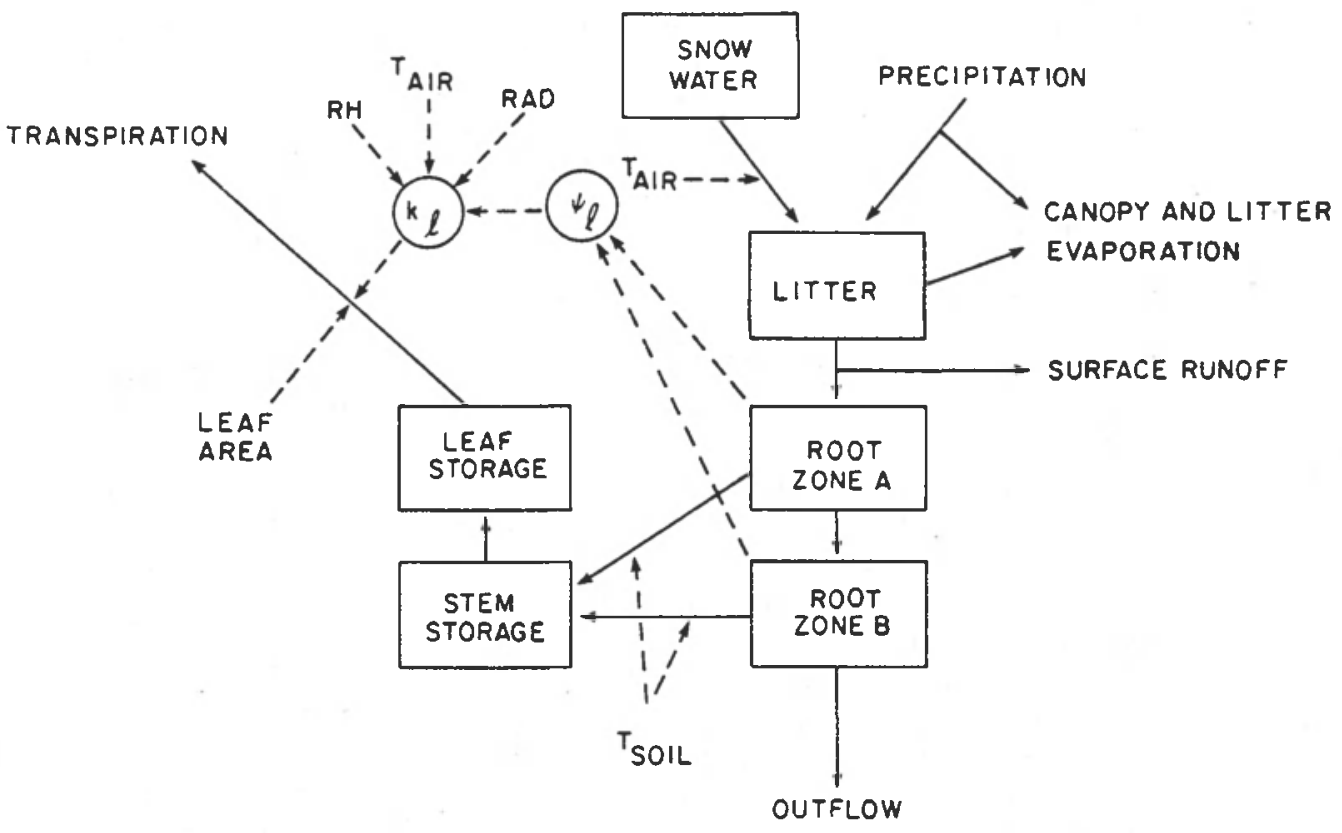

FiG. 1. H2OTRANS, a mass-balance simulation model used to estimate outflow. Solid lines indicate water flows, and dashed lines indicate influences on water flows of relative humidity $(R H)$, air temperature $\left(T_{A(R)}\right)$, soil temperature at $25 \mathrm{~cm}$ $\left(\mathrm{T}_{\text {sort }}\right)$, solar radiation $(\mathrm{RAD})$, leaf area, leaf conductance $\left(k_{\ell}\right)$, and predaun leaf water potential $\left(\psi_{\ell}\right)$. Six compartments are treated as state variables (boxes), and there are four summation compartments (outflow, transpiration, canopy and litter evaporation, and surface runoff). For other details see Study Area and Methods: Estimating Outflow.

flow from ecosystems have been done on watersheds with impervious bedrock, using weirs. During the last $10 \mathrm{yr}$, however, considerable progress has been made in modelling water flow through forest stands (Tan et al. 1978, Halldin 1979, Persson 1980, Black and Spittlehouse 1981, Sollins et al. 1981, Waring et al. 1981). These computer simulation models calculate outflow after integrating the factors or processes affecting water movement.

Transpiration is a major pathway for water loss from forests but is difficult to model, especially in situations where the actual evapotranspiration is considerably less than potential evapotranspiration, due to stomatal resistance. The success of forest outflow models often is determined by the extent to which the stomatal control of transpiration can be modelled. Considerable data have been accumulated on the transpiration and stomatal responses of lodgepole pine in our study area (Swanson 1967, Fetcher 1976, Fahey 1979, Running 1980a, b, c, Knight et al. 1981, Kaufmann 1982). This physiological information provided the basis for the development of a stand-level model (H2OTRANS; Running et al. 1983, Running 1984) from a single-tree model constructed originally for Douglas-fir (Waring and Running 1976).

H2OTRANS is a mass-balance model with 10 state variables (Fig. 1) and 5 driving variables: precipitation (excluding water in the snowpack), air temperature, relative humidity, soil temperature (at $0.25 \mathrm{~m}$ depth), and incoming shortwave radiation. The status of each state variable is calculated hourly, including the summation variables: transpiration, outflow, surface runoff, and evaporation. Subsurface outflow is calculated when water influx as rainfall or snow melt occurs at a time when the litter and root zone compartments are full. The model allows for slow drainage from a saturated soil profile (determined empirically by observing the rate of water table decline in soil pits). Data on soil hydraulic conductivity are not used by the model in its present form.

Our general approach was to (1) make careful measurements of snowpack water equivalent $(S)$, subsequent precipitation during the snow melt period $(P)$, and soil water change $(\Delta Q)$; (2) model transpiration and evaporation of water intercepted by the canopy (ET) during the drainage period; and (3) calculate drainage $(D)$ below the rooting zone using the relationship

$$
D=S+P-\Delta Q-E T .
$$

For the present analysis we set model parameters so that no surface runoff occurs, an assumption that is realistic for most sites in the lodgepole pine ecosystem and for all but one of our study areas. Transpiration is calculated by modelling the effects of soil water, air temperature, relative humidity, and solar radiation on 
leaf conductance $(k)$, with the model calculating one $k$, value for the forest canopy. Computation of a single canopy $k$ value fits the resolution of our modelling objectives and has been used with success by others (Sinclair et al. 1976, Luxmoore et al. 1978, Tan et al. 1978, Federer 1979, Halldin 1979, Lohammar et al. 1980). Transpiration rate $(T)$ is calculated as

$$
T=k, \times H D \times L A \times 3600,
$$

where $H D$ is the absolute humidity deficit (in grams per cubic centimetre) and $L A$ is leaf area per hectare. The units for $T$ are cubic centimetres per hectare per hour.

The simulation of water flow begins with the date snow melt is initiated as the snowpack becomes isothermal, which is determined by field measurements. Snow melt rate is calculated using an empirically derived degree-day function; constructing an energy budget model for snow melt was beyond the scope of our study. In the model, water passes into root zone $A$ after the litter is saturated, and similarly into the other storage comparments as the storage volume of the previous compartment is exceeded. Evaporation and transpiration occur continuously as conditions permit, with evaporation from the canopy and forest floor calcu. lated as a simple function of $H D$. Sublimation and evaporation from the snowpack and soil are not calculated by the model, nor is transpiration from understory vegetation; all are difficult to measure and are believed to constitute a small proportion of the hydrologic budget in our stands.

Tables 1 and 3 include values for the initial conditions and parameters that were used for simulating water movement through each of the eight stands. Certain parameters were constant for all stands: maximum mean canopy leaf conductance $(0.15 \mathrm{~cm} / \mathrm{s})$, maximum predawn leaf water potential $(-0.6 \mathrm{MPa})$, leaf osmotic potential $(-2.0 \mathrm{MPa})$, and the canopy interception coefficient $(.05 \mathrm{~cm} / \mathrm{LAI})$. Running (1984) provides more details on the structure of H2OTRANS.

\section{Model validation}

Model validation was an integral part of our research program, and separate data sets were collected for that purpose throughout our study. While most of the physiological data used to develop H2OTRANS were collected at a site in northern Colorado (Running $1980 a$, $b, c)$, the validation data were collected from our stands in nearby southern Wyoming. Predictions of outflow could not be validated, but several values calculated by H2OTRANS could be measured, namely predawn leaf water potential $\left(\psi_{\ell}\right)$, leaf conductance $\left(k_{\ell}\right)$, and soil water depletion. Simulated values for these parameters were compared to measured values. In addition, model estimates of hourly and daily transpiration were compared to values obtained using whole-tree potometers (Knight et al. 1981).

Soil water depletion (or recharge) was calculated by subtracting soil water volume measured at $t_{0+1}$ from that measured at $t_{0}$. Soil water depletion can be used for estimating summer $E T$, but not vernal transpiration (VT) in the spring. Actual $\psi$, was obtained between 0200 and 0500 on 5-6 mid-canopy twigs using a Scholander pressure chamber, and canopy $k$, was estimated from an average of $5-10$ values obtained at mid-canopy level using a null-balance, diffusion porometer (Beardsell et al. 1972). The $k_{\ell}$ data for validation were gathered from one of our study areas (Albany) in 1979 , with a set of data being collected at $2-h$ intervals on a clear day during the 1 st and 2 nd wk of each summer month.

\section{Results}

Our analysis of factors affecting water and nutrient outflow is dependent on the characteristics of the stands we chose to study and on the validity of H2OTRANS. Here we will first describe the features of our stands and then our evaluation of model adequacy. We will then proceed to an analysis of (1) water and nutrient outflow patterns on a seasonal and annual basis, and (2) simulation experiments that demonstrate the importance of certain stand features.

As noted previously, the eight study areas differed greatly in both vegetative and hydrologic features ( $\mathrm{Ta}$ bles 1 and 3). The climatic characteristics of the eight stands were similar, however, with daytime temperatures in the warmest stand (Albany) averaging $3^{\circ}-5^{\circ}$ above those in the coolest (French Creek), and with maximum radiation, maximum air temperature, and minimum relative humidity occurring in late June or during July (Fig. 2). Rainfall patterns in the stands also were similar during the 3-yr period (Fig. 4). Total annual rainfall accounted for $34-67 \%$ of annual precipitation, ranging from $23-31 \mathrm{~cm}$ (for all stands during $3 \mathrm{yr}$ ), with $20-40 \%$ of the rainfall occurring during the snow melt period.

Snow water equivalent ranged from a low of $10 \mathrm{~cm}$ in 1981 (Chimney Park) to a high of $89 \mathrm{~cm}$ at French Creek in 1980 , and varied annually during the 4-yr study period by as much as $300 \%$ (Dry Park II, Table 3). Snow melt usually began in April or early May but, depending on snowpack size, air temperature, and insolation, the duration of the snowpack varied among stands and among years (Fig. 3). The snow-free period at Dry Park II began $\approx 30 \mathrm{~d}$ earlier in 1977 than in 1979 (Fig. 3A). As discussed below, the duration of snow melt can affect outflow.

The soil is by far the largest ecosystem compartment for the storage of snow water. The maximum available soil storage in each stand ranged from 6 to $22 \mathrm{~cm}$ (Table 3). Soil water depletion continued through the summer, with small amounts of summer rain percolating to the soil on one or two occasions (Fig. 4). Soil drawdown occurred to a minimum observed water potential of $-1.0 \mathrm{MPa}$ at $15 \mathrm{~cm}$ depth and $-0.4 \mathrm{MPa}$ at $100 \mathrm{~cm}$ (Fahey and Young 1984). 


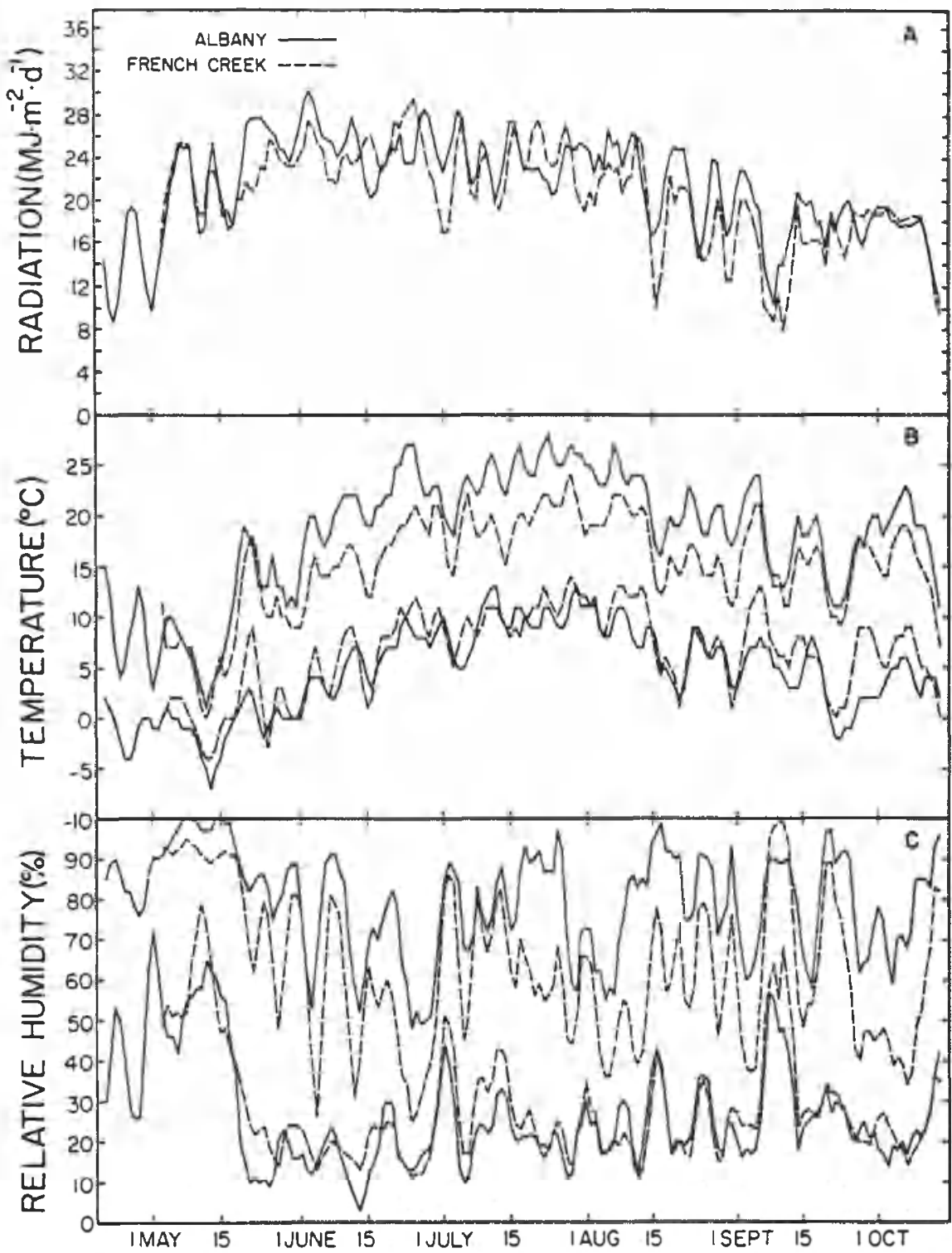

FlG. 2. Variation in solar radiation above the canopy and in air temperature and relative humidity in the canopy during the growing season of 1980 in the coolest (French Creek) and warmest (Albany) of the study areas. The data have been smoothed by $3-d$ averaging. Mean minimum and maximum values are shown for temperature and humidity.

The trenches in each stand provided an opportunity to observe soil drainage patterns. Little or no water accumulated in the trenches at Albany and Nash Fork, suggesting rapid drainage of gravitational water; however, water accumulated in the trenches at the other six stands. As will be shown, slow drainage amplified the effect of vernal transpiration on outflow.

Special hydrologic conditions also were observed at Rock Creek and the two stands at Chimney Park. Rock Creek has more clay in the soil (mass at $0-15 \mathrm{~cm}$ depth $=$ $39 \%$ of $<2-\mathrm{mm}$ fraction) than the other stands, which led to slower infiltration and considerable surface runoff in both 1979 and 1980. Our attempts to measure surface runoff at Rock Creek were unsuccessful and, consequently, we have not been able to calculate a water budget for that stand.

The two Chimney Park stands occur at the lower part of a catchment and, although no surface runoff occurred, lateral subterranean flow probably occurred over the shallow $(1 \mathrm{~m})$ bedrock. We could not measure the quantity of subterranean infow, and consequently we could not calculate hydrologic budgets for these two stands.

\section{Model validation}

H2OTRANS was run for 1979, 1980, and 1981, using stand-specific and year-specific input data for five of the eight stands. In this section we compare certain 
model predictions with field measurements to evaluate the adequacy of the model for estimating subsurface water outflow.

Predawn leaf water potential ( $\psi$ ) and leaf conductance $(k)$. - The observed and predicted values of $\psi$, diverged considerably at Nash Fork, but a close correspondence between the values was noted at Albany and Dry Park (Fig. 5). At Nash Fork the model predicted much greater predawn water stress than was actually observed, but this divergence proved to be inconsequential to predictions of transpiration because of the fact that $k$, was reduced to near zero by the model well before the low $\psi$, values were reached. The correspondence between predicted and observed midday $k_{\ell}$ was good (Fig. 6).

Soil water depletion and evapotranspiration. - Comparing model predictions to measured soil water values was viewed as a critical validation test, and the results were encouraging (Fig. 4). In most cases the model predicted soil water content to within $2 \mathrm{~cm}$ during June and July. A notable discrepancy did occur in late summer, with the model predicting more water left in the soil than was actually observed. However, error at this time of year was not critical to our present analysis, because outflow does not occur in late summer and we did not depend on the model for an estimate of storage capacity for the following spring snow melt. The discrepancy between observed and predicted soil water values for French Creek may be attributable to our lack of transpiration estimates for the understory vegetation, which is relatively more abundant there (Table 1).

In general, the model did not predict accurately the quantity of soil water recharge after summer rains. This problem resulted from an inadequate data base on canopy interception, a process that depends on rainfall duration and intensity and on intermittent evaporation (Rutter et al. 1972). Our data were inadequate to suggest how the canopy interception coefficient should vary from one stand to another, but our value of 0.05 $\mathrm{cm} / \mathrm{LAI}$ obviously led to an overestimation of interception in some stands and underestimation in others (Fig. 4). This deficiency is not critical to our present analysis, but the problem would be amplified if H2OTRANS were used to simulate conditions over $>1$ yr.

As with the $\psi_{\varepsilon}$ and $k_{\varepsilon}$ data, the qualitative behavior of the model in predicting soil water depletion was logical. Soil recharge was indicated only after sufficient rainfall had occurred, due to complete interception of other rainfall, and a surge in transpiration occurred following these recharge events (Fig. 4). Also, outflow was predicted only during and just after the snow melt period, and early spring transpiration was retarded (Fig. 4) as would be expected due to the nighttime frost effect (represented in the model by retarding stomatal opening as a linear function of below-freezing temperatures; Fahey 1979). On clear days in June the predicted 24-h transpiration rate was $0.38 \mathrm{~cm}$ at Nash Fork and $0.31 \mathrm{~cm}$ at Dry Park, values which are close to the 0.34 $\mathrm{cm}$ estimated with whole-tree potometers (Knight et al. 1981). The onset of water stress was predicted sooner than observed in the field, resulting in underestimation of summer transpiration, but this discrepancy did not affect the estimation of outflow that we desired.

Based on the analysis above, we conclude that H2OTRANS is adequate for predicting transpiration during the snow melt period and capable of giving reasonable estimates of outflow below the rooting zone for stands with no subterranean inflow. Further improvements are required before the model can be run for several years in sequence or applied to stands with (1) more than one dominant tree species, (2) abundant understory vegetation, (3) outflow events following summer rains, or (4) lateral flows of soil water. The required improvements would include better treatments of snow melt, canopy interception, and soil water flux.

Water outfow, interception, and transpiration.Water outflow beyond the rooting zone was indicated by the model only during the snow melt period and was highest at Albany, with an estimated total outflow of $43 \mathrm{~cm}$ in 1979 and $18 \mathrm{~cm}$ in the low snowfall year of 1981 (Fig. 4). Albany had the lowest LAI and soil storage capacity. The least outflow occurred from the two Dry Park stands, where high soil storage capacity

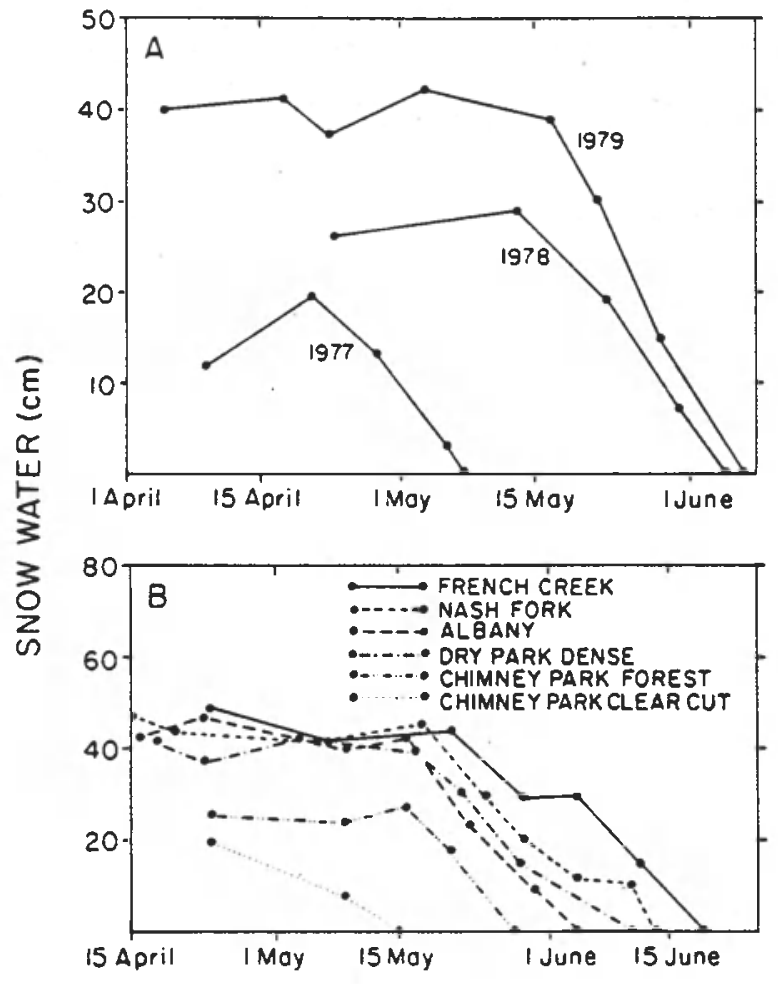

Fig. 3. Variation in snow ablation from the study areas. (A) Annual variation at Dry Park II. (B) Interstand variation in 1979. Coefficients of variation were usually $<10 \%$. 


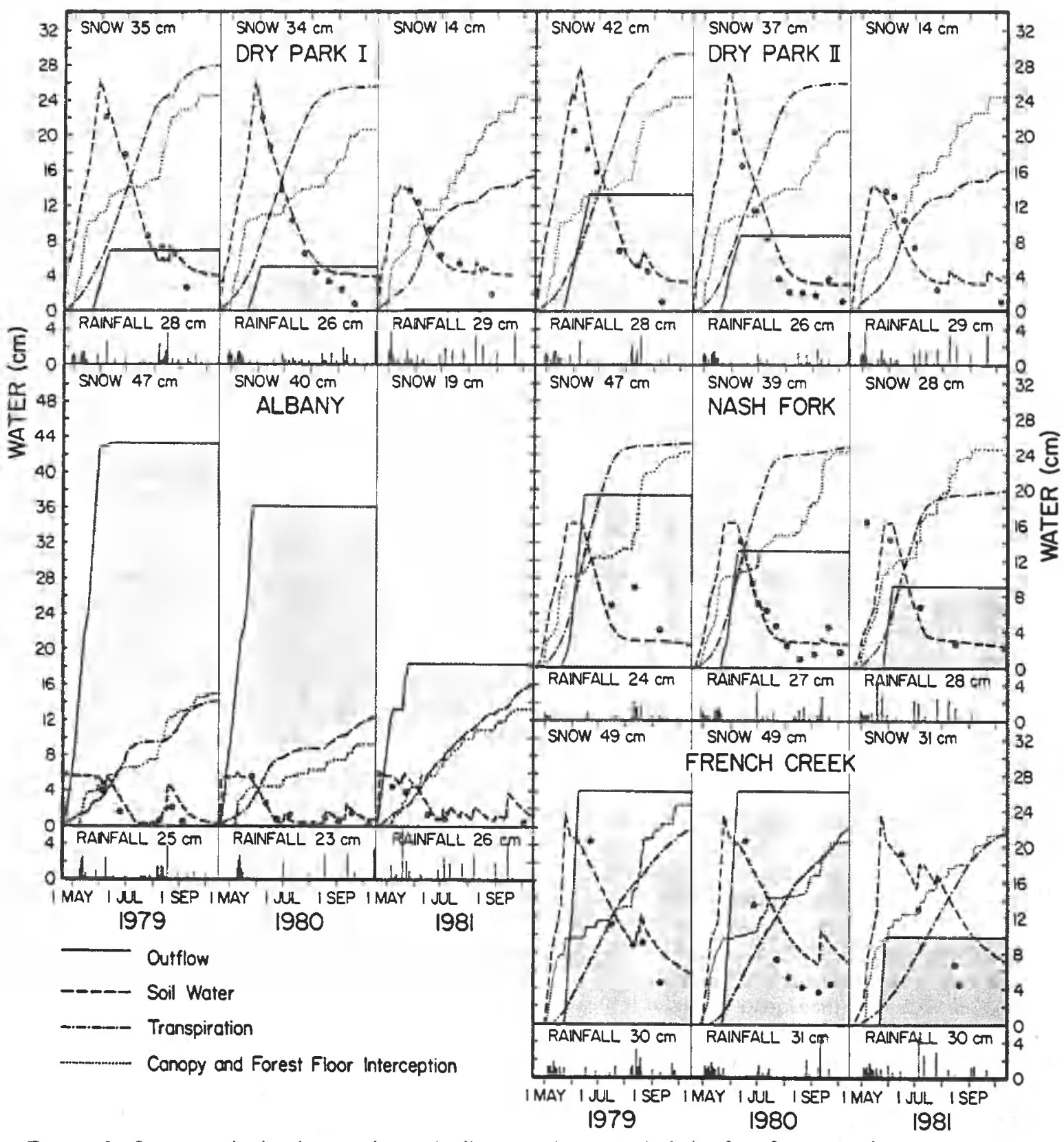

Fig. 4. Outflow, transpiration, interception, and soil water recharge and depletion from five contrasting stands as calculated by H2OTRANS for 1979, 1980, and 1981. Shaded areas indicate outflow volumes. Data points $(0)$ indicate soil water content as measured by neutron thermalization (coefficients of variation usually were $<10 \%$ at Albany, $<15 \%$ at Dry Park, and $<20 \%$ at Nash Fork and French Creek). Annual total water inputs in the form of snow and rainfall are given for each stand and year. Individual rainfall events are also shown. Note the response of transpiration to summer rainfall, and the reduced transpiration rates in midsummer, except at French Creek, which is more mesic.

and a prolonged VT period (due to slow drainage and snow melt) combined to reduce predicted outflow to only $7 \mathrm{~cm}$ in 1979 and to zero in 1981 .

Canopy and forest floor interception prevented complete soil moisture recharge in the summer. The model calculated rainfall interception values ranging from 13 $\mathrm{cm}$ at Albany, where the LAI and forest floor mass were low, to a maximum of $25 \mathrm{~cm}$ at Nash Fork, where surface area and forest floor mass were high. At French Creek, Nash Fork, and Albany the model estimates for total water intercepted often were similar to the estimates for total amount transpired (Fig. 4).

Estimates of total annual transpiration and $E T$ ranged from lows of 12 and $21 \mathrm{~cm}$, respectively, at Albany (1980, Fig. 4) to highs of 29 and $53 \mathrm{~cm}$ at Dry Park II (1979, Fig. 4). For all stands and years, transpiration 
accounted for $50-61 \%(\bar{x}=55 \%, n=15)$ of $E T$ as estimated by H2OTRANS, which does not consider winter evaporation or sublimation. Estimated water loss by VT was $2-11 \mathrm{~cm}$, or $9-44 \%(\bar{x}=25 \%, n=13)$ of total transpiration and $5-22 \%(\bar{x}=13 \%, n=13)$ of $E T$. Estimated $E T$ during the spring, summer, and fall accounted for $33-95 \%$ of total annual precipitation $(\bar{x}=73 \%$ ) during the 3 -yr study period; the percentage was lowest at Albany, where leaf area, VT, and soil storage capacity were low. Stomatal control appears to reduct $E T$ later in the summer, though summer rains can lead to the resumption of rapid transpiration (Fig. 4).

Estimated VT and outflow varied considerably among the five stands for which a water budget could be calculated, with VT accounting for 4-20\% of the snow water in 1980 (Fig. 7). Outflow accounted for $11-75 \%$ of the 1980 snow water. Comparing the Albany, Nash Fork, and Dry Park stands illustrates that the quantity of outflow can be quite different even though water input is nearly the same, whereas comparing Nash Fork

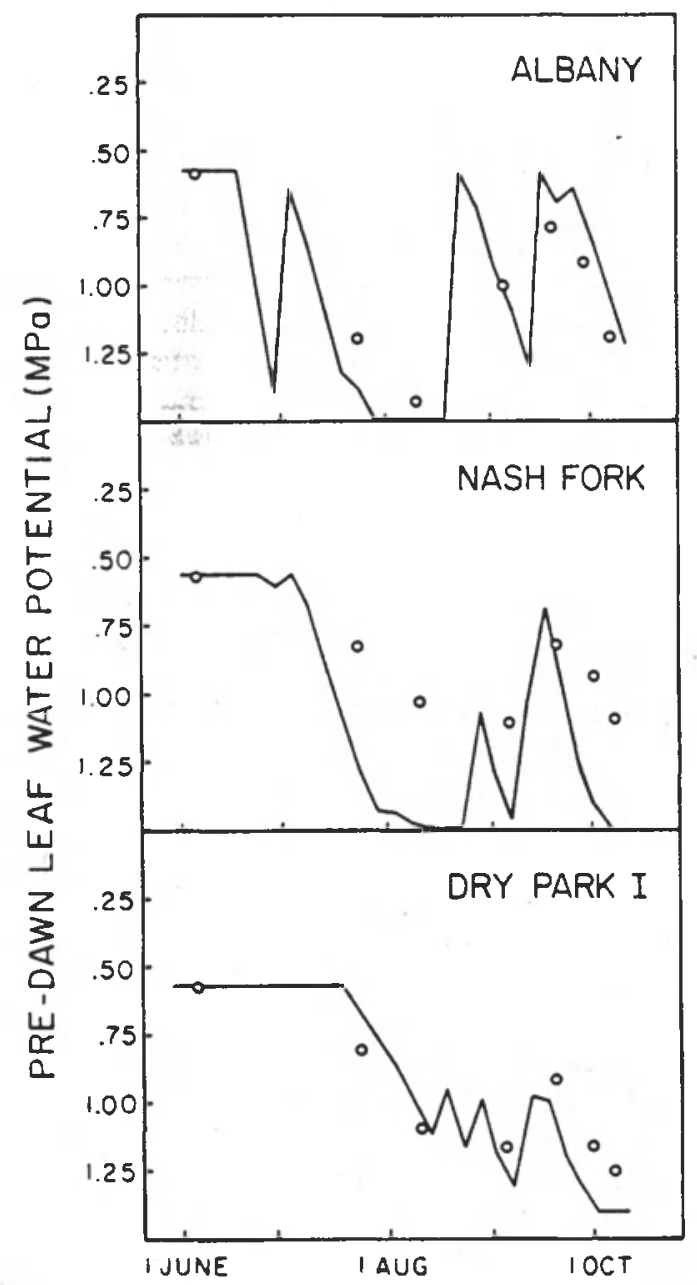

Fig. 5. Observed $(O)$ and simulated $(-)$ variation in predawn leaf water potential ( $\mathrm{MPa}$ ) at Albany, Nash Fork. and Dry Park I in 1980.

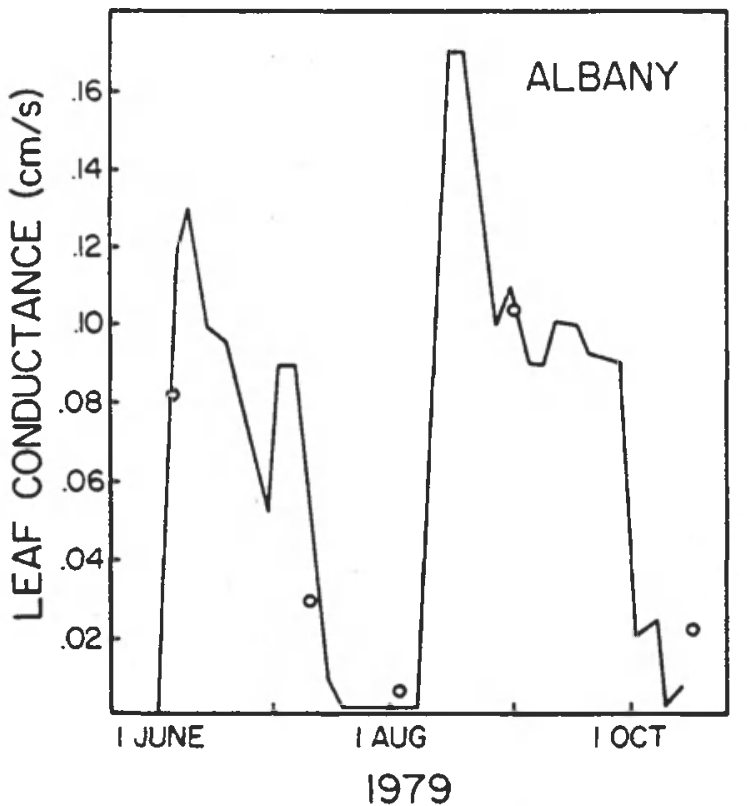

FiG. 6. Observed $(O)$ and simulated $(\longrightarrow$ midday leaf conductance at Albany in 1979.

to Dry Park I shows that outflow can be different even though forest structure, soil storage capacity, and water input are similar (Fig. 7). Interestingly, the two Dry Park stands were very similar in both VT and outflow despite their great difference in structure (Table 1), as noted by Knight et al. (1981).

To estimate nutrient outflow we needed a stand hydrograph showing daily water outflow rate during the entire outflow period. Fig. 8 represents our attempt to produce such hydrographs for 1980 , but a major deficiency must be acknowledged, namely that percolation through the soil profile is treated simplistically by H2OTRANS and thus the dips, peaks, or plateaus in daily outflow rate may not be accurate. However, because of close correspondence between measured and predicted soil water depletion rates, we think that total outflow for a period of a week or more is estimated reasonably well.

Though predicting daily outflow rates is beyond the scope of H2OTRANS, it is useful to compare the stand hydrographs in Fig. 8. The initiation of outhow probably begins earliest at Albany because of (1) its lower elevation and $\mathrm{LAI}$, which contribute to early snow melt, and (2) the fact that less snow water is required to exceed the storage capacity of this stand. Outflow occurs over a longer period because snow melt may be slow initially, except on occasional warm days (which coincide with the outflow peaks) and because more water moves as outflow due to lower storage capacity and less vernal transpiration. The low dip in the Albany hydrograph during 10-15 May coincides with a cold period when little snow melt occurred. Outflow from both the Nash Fork and Dry Park stands began $\approx 1$ 


\section{WATER BUDGETS FOR OUTFLOW PERIOD IN 1980}

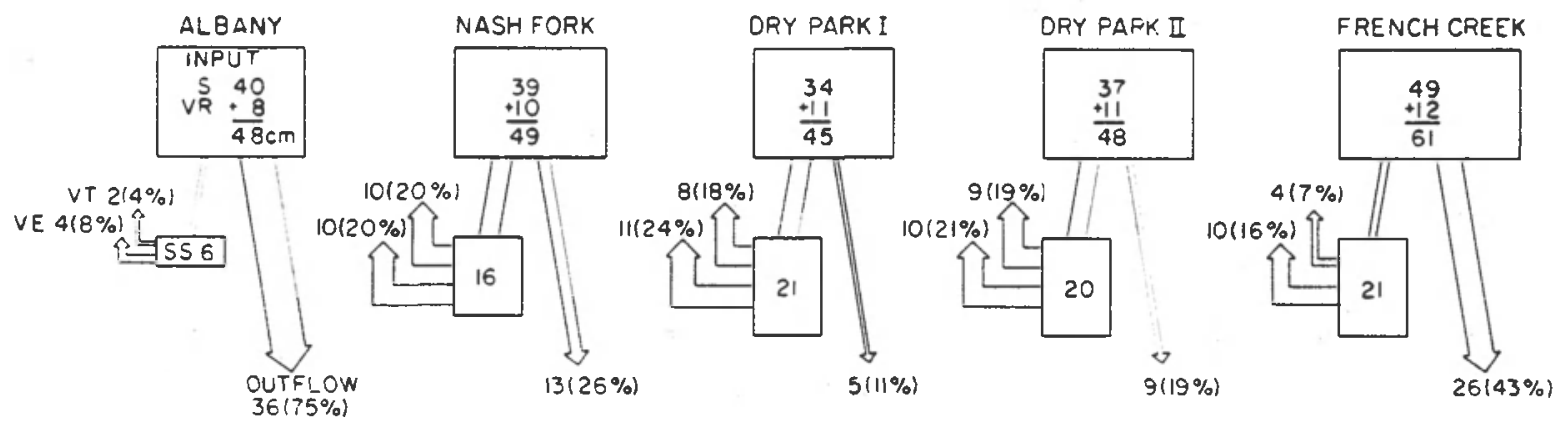

FIG. 7. Diagrams depicting the water budgets (in $\mathrm{cm} \mathrm{H} \mathrm{H}_{2} \mathrm{O}$ ) of five contrasting stands during the 1980 outflow period (from the initiation of snow melt until the end of drainage). For annual budgets see Fig. 4. The amount added to the value for maximum snow water equivalent (S) is vernal rainfall (VR), i.e., rainfall that occurred during the snow melt period. The smaller boxes, for soil storage (SS), are full at the end of the outllow period, and the percentages in parentheses indicate the proportion of S + VR flowing via outflow, vernal transpiration (VT), and vernal interception (VE) during the outflow period (as estimated by H2OTRANS).

mo later than Albany, due to later initiation of snow melt, more soil storage, and more VT. The retarded drainage at Dry Park is obvious.

Element input and outflow. - Element concentrations in bulk precipitation were comparable to other values in the literature for the region (Stottlemeyer and Ralston 1970, Lewis and Grant 1979). Weighted mean annual concentrations (in milligrams per litre) for total $\mathrm{N}, \mathrm{K}, \mathrm{P}$, and $\mathrm{Ca}$ in snow water and in rain were, respectively: total $\mathrm{N}$ (mostly $\mathrm{NO}_{3}{ }^{-}$and $\mathrm{NH}_{4}{ }^{+}$), $0.17 \mathrm{mg}$ / $\mathrm{L}$ in snow water, $0.56 \mathrm{mg} / \mathrm{L}$ in rain; $\mathrm{K}, 0.08 \mathrm{mg} / \mathrm{L}$, $0.23 \mathrm{mg} / \mathrm{L}$; total $\mathrm{P}, 0.004 \mathrm{mg} / \mathrm{L}, 0.010 \mathrm{mg} / \mathrm{L}$; and $\mathrm{Ca}$, $0.26 \mathrm{mg} / \mathrm{L}, 0.83 \mathrm{mg} / \mathrm{L}$. These values were multiplied by the corresponding volumes of snow water and rain to provide an estimate of total annual input via bulk precipitation (Table 4). We do not have values for aerosol impaction on plant surfaces, which can be another source of nutrients (White et al. 1971, Schlesinger and Reiners 1974, Gorham et al. 1979), and therefore our estimates of atmospheric input are probably low.

Concentrations of $\mathrm{N}, \mathrm{P}, \mathrm{K}, \mathrm{Na}$, and $\mathrm{Ca}$ in the soil solution changed significantly $(P<.05)$ in most of the stands as the 1982 snow melt season progressed (Fig. 9). TKN concentration declined for $\approx 30 \mathrm{~d}$ before increasing slightly. Other elements had different patterns of change in different stands. For example, $\mathrm{Ca}, \mathrm{Mg}$, and $\mathrm{Na}$ were present at relatively high levels and tended to increase during the snow melt period at Nash Fork and Dry Park, while a decline was observed in the concentrations of the same elements at French Creek and Albany. In all cases, however, the mean concentrations of $\mathrm{Ca} . \mathrm{Mg}, \mathrm{K}$, and $\mathrm{Na}$ in soil solution were significantly higher than in snow water. Snow and subsoil solution did not differ significantly in total $\mathrm{N}$ and $P$ concentrations, but, as observed also by Sollins et al. (1980), most of the $\mathrm{N}$ in soil solution was in organic forms (not the $\mathrm{NH}_{4}{ }^{+}$and $\mathrm{NO}_{3}^{-}$that predominated in bulk precipitation). Fahey (1977) observed similar patterns in a nearby study area.

To calculate nutrient outflow, the element concentrations in deep soil water (Fig. 9) were multiplied by the quantity of outflow predicted (Fig. 8) during the 4$7 \mathrm{~d}$ intervals between collections. Nutrient outflow was then summed over all periods to provide an estimate of total nutrient outflow, expressed both as kilograms per hectare per year and as a ratio of nutrient outflow to atmospheric input (bulk precipitation). As can be seen in Table 5, considerable variation in element outflow was predicted; $N$ outflow varied among stands by a factor of $12\left(0.09-1.12 \mathrm{~kg} \cdot \mathrm{ha}^{-1} \cdot \mathrm{yr}^{-1}\right), \mathrm{P}$ by a factor of $6\left(0.01-0.06 \mathrm{~kg} \cdot \mathrm{ha}^{-1} \cdot \mathrm{yr}^{-1}\right), \mathrm{K}$ by a factor of $17(0.17$ $\left.2.9 \mathrm{~kg} \cdot \mathrm{ha}^{-1} \cdot \mathrm{yr}^{-1}\right), \mathrm{Ca}$ by a factor of $1.3(8.7-10.9$ $\left.\mathrm{kg} \cdot \mathrm{ha}^{-1} \cdot \mathrm{yr}^{-1}\right), \mathrm{Na}$ by a factor of $1.9\left(2.8-5.2 \mathrm{~kg} \cdot \mathrm{ha}^{-1}\right.$. $\left.\mathrm{yr}^{-1}\right)$, and $\mathrm{Mg}$ by a factor of $1.6\left(2.7-4.5 \mathrm{~kg} \cdot \mathrm{ha}^{-1} \cdot \mathrm{yr}^{-1}\right)$. Compared to outflow estimates from several International Biological Program (IBP) sites (Cole and Rapp 1981), our estimates are on the low ends of the ranges for $\mathrm{N}$ and $\mathrm{K}$ (IBP values: $0.6-14.9$ and $1.0-8.9 \mathrm{~kg}$. $\mathrm{ha}^{-1} \cdot \mathrm{yr}^{-1}$, respectively) but closer to the middle of the ranges for $\mathrm{P}, \mathrm{Ca}$, and $\mathrm{Mg}$ (IBP values: $0.02-0.20,2.3-$ 59.8 , and $0.45-6.0 \mathrm{~kg} \cdot \mathrm{ha}^{-1} \cdot \mathrm{yr}^{-1}$, respectively).

Nutrient outflow was replenished to varying degrees by atmospheric input; there was a calculated net accumulation in $\mathrm{N}$ for each of the stands and calculated net accumulations in $\mathrm{K}$ and $\mathrm{P}$ at Nash Fork and both Dry Park stands (Table 5). We did not measure denitrification, but this pathway for $\mathrm{N}$ loss is believed to be low in our stands because conditions $\left(\mathrm{NO}_{3}{ }^{-}\right.$in solution, flooding accompanied by high microbial activity) favoring that process are uncommon in lodgepole pine forest ecosystems. Nutrient outflow/atmospheric input ratios were consistently $>1.0$ for $\mathrm{Ca}, \mathrm{Na}$, and $\mathrm{Mg}$, but, due to a lack of data on weathering, such 
ratios cannot be interpreted as suggesting net losses. The stands may or may not be in steady state for soilderived elements, but they appear to be accumulating $\mathrm{N}$ and perhaps $\mathrm{P}$ and $\mathrm{K}$.

\section{Simulation studies}

The results presented thus far are for conditions observed during the 1979-1982 study period. Questions now arise about outflow under different conditions. Here we describe the effects predicted using H2OTRANS of (1) varying snowpack water equivalent, holding constant LAI, soil storage capacity, temperature, rainfall, and all other characteristics; and (2) reducing LAI to nearly zero, thereby increasing snow melt rate and reducing the potential for canopy interception and VT.

The first simulation was done using three contrasting stands and realistically high $(60 \mathrm{~cm})$, low $(10 \mathrm{~cm})$, and intermediate values for maximum snow water equivalent. The model suggests a linear or nearly linear increase in outflow with increasing snow water in all three stands (Fig. 10). At Albany predicted outflow was highest and increased most rapidly with additional snow, whereas outflow was lower and less responsive to snowpack size at Nash Fork and Dry Park, stands with greater capacity for water storage and VT. The results suggest that a snowpack water equivalent of $10 \mathrm{~cm}$ would cause outflow of 0,0 , and $7 \mathrm{~cm}$ at Dry Park, Nash Fork, and Albany, respectively, given the conditions of those stands in 1980 (Fig. 10).

To calculate the effect of varying snowpack on nutrient outflow, stand-specific element concentrations for specific times were multiplied, as before, by the quantity of outflow predicted by H2OTRANS for the period since the last soil water sample. With very little snow (and outflow), the chemical composition of the outflow is largely that of the early soil water samples, whereas with a larger snowpack the amount of element loss is affected by concentrations observed later in the outflow period. The predicted losses of $\mathrm{N}, \mathrm{K}, \mathrm{P}$, and $\mathrm{Ca}$ generally varied in a nonlinear manner with the quantity of outflow, with the shape and average slope of the curve differing with different stand characteristics (Fig. 11). If water outflow were to triple (from 12 to $36 \mathrm{~cm}$ ) at both Albany and Nash Fork, our calculations suggest that $\mathrm{N}$ outflow would be multiplied by 2.5 (from 0.4 to $1.0 \mathrm{~kg} \cdot \mathrm{ha}^{-1} \cdot \mathrm{yr}^{-1}$ ) at Albany, and would double (from 0.1 to $0.2 \mathrm{~kg} \cdot \mathrm{ha}^{-1} \cdot \mathrm{yr}^{-1}$ ) at Nash Fork. Comparable values for $K$ are three times (1.0-3.0 $\left.\mathrm{kg} \cdot \mathrm{ha}^{-1} \cdot \mathrm{yr}^{-1}\right)$ at Albany and a factor of $2.2(1.7-3.8$ $\left.\mathrm{kg} \cdot \mathrm{ha}^{-1} \cdot \mathrm{yr}^{-1}\right)$ at Nash Fork. $\mathrm{N}$ and $\mathrm{P}$ outflow increased much less rapidly with increasing water outflow than $\operatorname{did} \mathrm{K}$ and $\mathrm{Ca}$.

Increasing the snow-water equivalent causes more nutrient outflow, but there is a corresponding increase in nutrient input from the additional snow. In order to place the simulated outflow values into perspective, the ratio of outflow to atmospheric input was calculated for varying amounts of snow water. Rainfall remained the same for all simulations. Element outflow was calculated as described above, whereas input was calculated as the sum of inputs from the snowpack and summer rains. Although ratios $<1.0$ indicate nutrient accumulation, ratios $>1.0$ cannot be interpreted as a net loss without additional data on aerosol impaction and weathering.

The simulation results suggest that even the highest levels of snow water are inadequate to cause a net loss

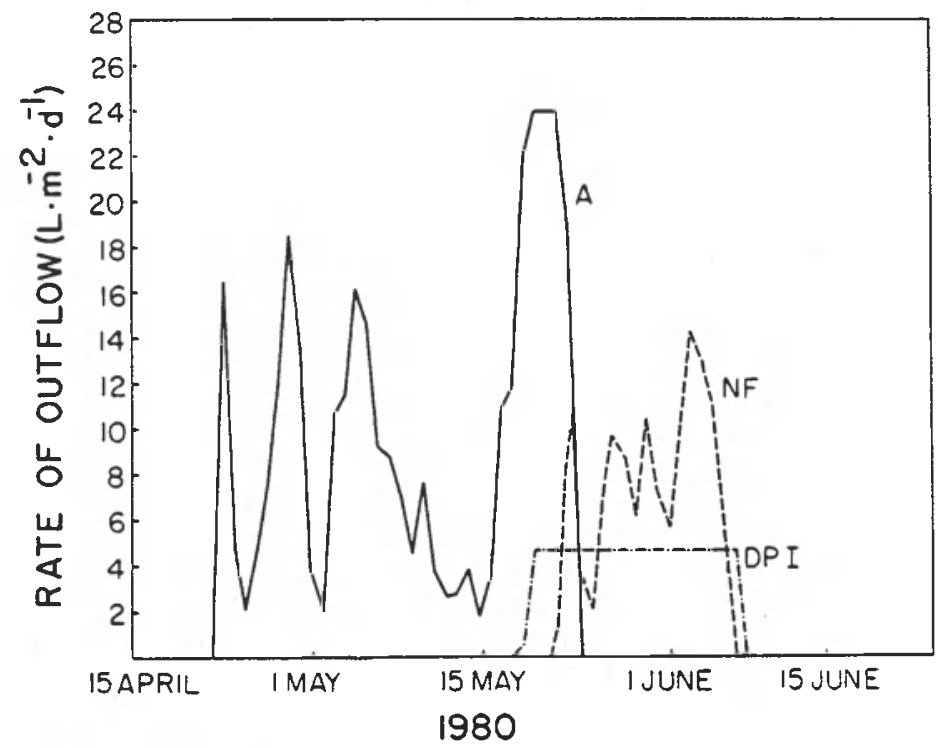

FIG. 8. Simulated stand hydrographs for three contrasting stands in 1980. A = Albany. NF $=$ Nash Fork, DP I $=$ Dry Park I. Due to limitations of H2OTRANS. only the general pattern of outflow is meaningful (see Results: Water Outflow, Interception, and Transpiration). 
of $\mathrm{N}$ in our study areas (Fig. 12). The outflow/input ratios for $\mathrm{P}$ and $\mathrm{K}$ are more variable and may exceed 1.0 with increasing snow water in some stands (Fig. 12).

A second simulation was performed to study the effect on water outflow of reducing LAI (to 0.1 ), as might occur after a timber harvest. For the model to be realistic, variables other than LAI had to be changed also (Luxmoore et al. 1981). First, the microclimatic conditions in an area with low LAI are considerably different than in dense forest. At Chimney Park we monitored air temperature and humidity both in a clearcut and in the adjacent forest; these climatic data were used in conjunction with the stand data for Nash Fork and Albany. We chose these two stands because we felt most confident about the predicted water budgets there and because they represented quite different stand conditions, Nash Fork having much higher LAI and soil storage capacity than Albany (Table 1).

Soil storage capacity was also changed because we decided to simulate 2 nd-yr outflow, i.e., outflow from a stand where LAI reduction had greatly restricted soil water drawdown during the first growing season, thereby causing a much reduced storage capacity for the following spring. For our simulation we assumed a storage capacity of $3 \mathrm{~cm}$ rather than $14 \mathrm{~cm}$ at Nash Fork and $2 \mathrm{~cm}$ rather than $6 \mathrm{~cm}$ at Albany. Increasing storage capacity by $3 \mathrm{~cm}$ made little difference in simulated outflow. Snowpack water equivalent and rainfall were assumed to be equal for the two stands.

The most striking result of the harvest simulation was a much greater increase in water outflow at Nash Fork than at Albany (Fig. 13), a pattern which can be attributed to the removal of a larger amount of biomass and leaf area at Nash Fork. Outflow increased by only $36 \%$ at Albany (from 36 to $49 \mathrm{~cm}$ ), whereas outflow at Nash Fork increased by $277 \%$ (from 13 to $49 \mathrm{~cm}$ ). Outflow at Nash Fork was $20 \%(13 \mathrm{~cm})$ of the total annual precipitation $(66 \mathrm{~cm})$ before the simulated harvest and $74 \%(49 \mathrm{~cm})$ the second year after harvest, whereas outflow at Albany was $55 \%(36 \mathrm{~cm})$ of annual precipitation prior to harvest and $74 \%(49 \mathrm{~cm})$ after. A decrease in total $E T$ was indicated for both stands,

TABLE 4. Nutrient inputs $\left(\mathrm{kg} \cdot \mathrm{ha}^{-1} \cdot \mathrm{yr}^{-1}\right)$ in the bulk precipitation of three stands in the Medicine Bow Mountains, Wyoming (1979-1980).

\begin{tabular}{cccc}
\hline & \multicolumn{3}{c}{ Stand } \\
\cline { 2 - 4 } Element & Albany & Nash Fork & Dry Park \\
\hline $\mathrm{N}^{*}$ & 1.60 & 1.72 & 1.55 \\
$\mathrm{P}+$ & 0.03 & 0.04 & 0.03 \\
$\mathrm{~K}$ & 0.90 & 0.95 & 0.86 \\
$\mathrm{Ca}$ & 2.48 & 2.69 & 2.41 \\
$\mathrm{Na}$ & 0.96 & 1.04 & 0.93 \\
$\mathrm{Mg}$ & 0.41 & 0.44 & 0.40 \\
\hline
\end{tabular}

* Total Kjeldahl nitrogen plus nitrate.

$\dagger$ Total organic and inorganic phosphorus.

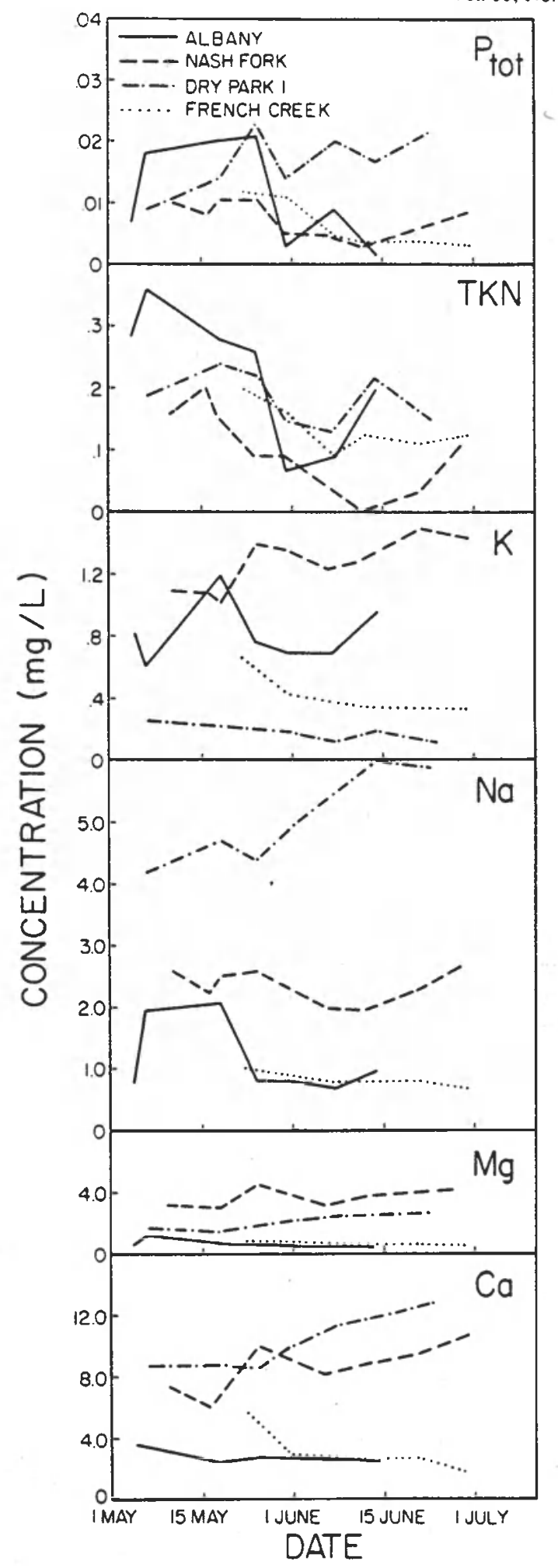

FIG. 9. The concentration of various elements in 1982 soil water samples collected at the bottom of the rooting zone in Give stands. The data from Dry Park I and Dry Park II were averaged, as they were not significantly different. For most elements, concentrations changed significantly with time $(P<.05)$. TKN $=$ total Kjeldahl nitrogen plus nitrate. 
from $80 \%$ of annual precipitation to $26 \%$ at Nash Fork and from 45 to $26 \%$ at Albany (Fig. 13).

We had hoped to estimate nutrient outflow after the simulated harvest, but our data are still insufficient to show how outflow water chemistry changes following timber harvest. Stark (1979), Hart et al. (1981), and C. P. P. Reid et al. (personal communication) provide data on element concentrations in soil solutions before and after timber harvest in our region, but no outflow estimates.

\section{General Discussion}

Water and nutrient outflow during the annual spring flush clearly varies substantially among sites in the lodgepole pine ecosystem. Stands differing in site or habitat type (Pfister 1981) experience different rates of water and element losses at different times during the snow melt period, and contribute differentially to streamwater quality and hydrograph shape. Furthermore, as illustrated by our simulation experiments, outflow from different parts of a catchment may change considerably or only slightly following perturbations and/or fluctuations in annual snow-water equivalent. Much of the observed variability can be attributed to the degree of biotic control, with nutrient outflow being affected by a different combination of factors than water outflow.

Initially we hypothesized that subsurface outflow of water from some stands during certain years could be reduced to zero. Such a situation was indicated by H2OTRANS at Dry Park in 1981. The frequency of such an occurrence may be high or low, depending on stand characteristics, and can be caused by various combinations of factors. In the simplest case, the maximum snow water is inadequate to saturate the soil profile, as was the case in 1981 at Dry Park, but outflow can also be reduced under conditions maximizing the amount of VT. Factors that tend to produce a high rate of VT include high evergreen LAI, climatic conditions favorable to VT, and a reduced rate of snow melt and percolation. LAI at the time of snow melt is a key

TABle 5. Estimated total outflow $\left(\mathrm{kg}^{\mathrm{h}} \mathrm{ha}^{-1} \cdot \mathrm{yr}^{-1}\right)$ and the ratios of outflow to atmospheric input (in parentheses) for three contrasting stands in the Medicine Bow Mountains, Wyoming, and six elements during 1980 . Input values are in Table 4.

\begin{tabular}{cccc}
\hline & \multicolumn{3}{c}{ Stand } \\
\cline { 2 - 4 } Element & Albany & Nash Fork & Dry Park \\
\hline $\mathrm{N}^{*}$ & $1.12(0.7)$ & $0.09(0.1)$ & $0.16(0.1)$ \\
$\mathrm{P}^{\dagger}$ & $0.06(2.0)$ & $0.01(0.3)$ & $0.01(0.3)$ \\
$\mathrm{K}$ & $2.94(3.3)$ & $0.93(0.9)$ & $0.17(0.2)$ \\
$\mathrm{Ca}$ & $9.60(3.8)$ & $10.91(4.1)$ & $8.74(3.6)$ \\
$\mathrm{Na}$ & $5.22(5.4)$ & $2.82(2.7)$ & $4.37(4.7)$ \\
$\mathrm{Mg}$ & $2.73(6.7)$ & $4.48(10.2)$ & $3.02(7.5)$ \\
\hline
\end{tabular}

- Total Kjeldahl nitrogen plus nitrate; nitrate concentration was consistently $<.01 \mathrm{mg} / \mathrm{L}$ in soil solutions.

† Total organic and inorganic phosphorus.

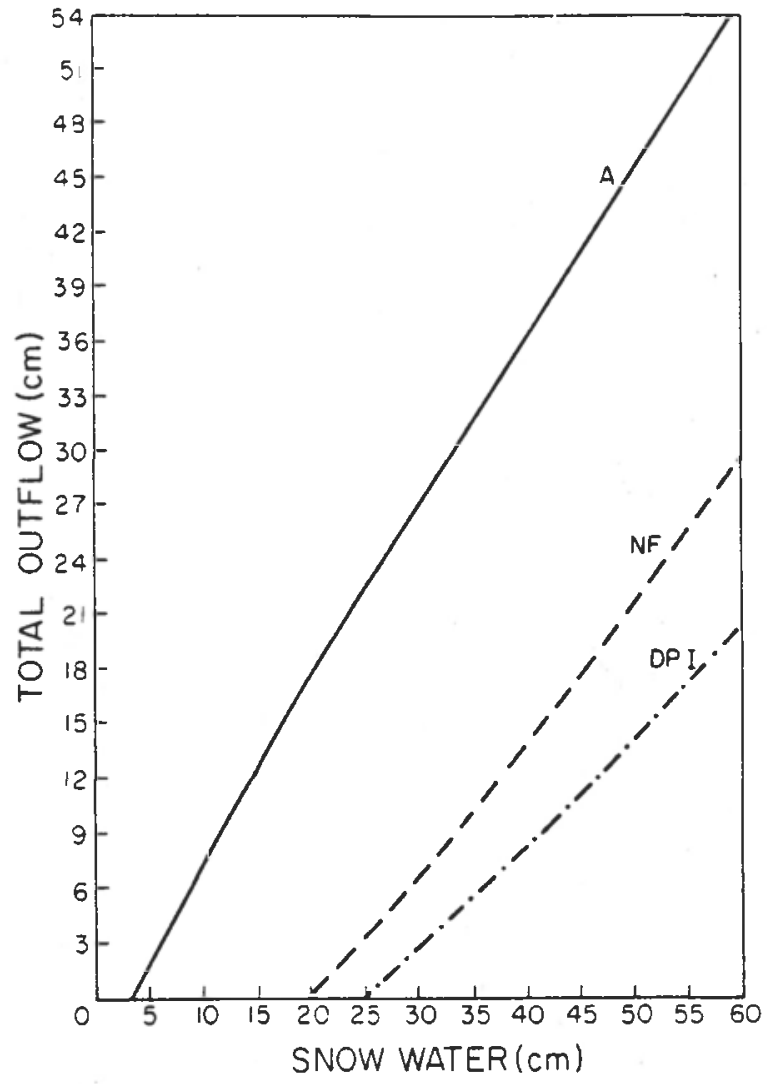

Fig. 10. Simulated water outflow from Albany (A), Nash Fork (NF), and Dry Park I (DP I) under varying conditions of snow water.

factor, not only because VT occurs through the leaves but also because the leaf area shades the snowpack, thereby prolonging snow melt and, consequently, the VT period. Topography is another factor, as north slopes with less intense radiation may have a longer VT period than south slopes (Alexander and Watkins 1977). Up to $20 \%$ or more of the snowpack water may flow by VT in some stands (Fig. 7).

Summer $E T$ is also important in providing storage capacity in the soil for the following spring, with soil water depletion occurring to a depth of $>2 \mathrm{~m}$ (Dahms 1971, Dietrich and Meiman 1974, Johnston 1975). Both VT and ET are dependent on LAI (and root area), which can be reduced by natural perturbations or land management practices. Watershed managers know that streamfiow often increases following LAI reduction, whether by insects (Love 1955, Bethlahmy 1974), timber harvest (Douglass 1967, Leaf 1975), or fire. Our results suggest that the increase in water outflow following harvesting is dependent in part on the amount of leaf area removed, a stand feature that is dependent on site quality (Grier and Running 1977, Waring et al. 1978) and, in unmanaged stands, relatively independent of natural stand denisty or basal area (Knight et al. 1981). Characterizing habitat types in terms of leaf area could be helpful in refining watershed manage- 


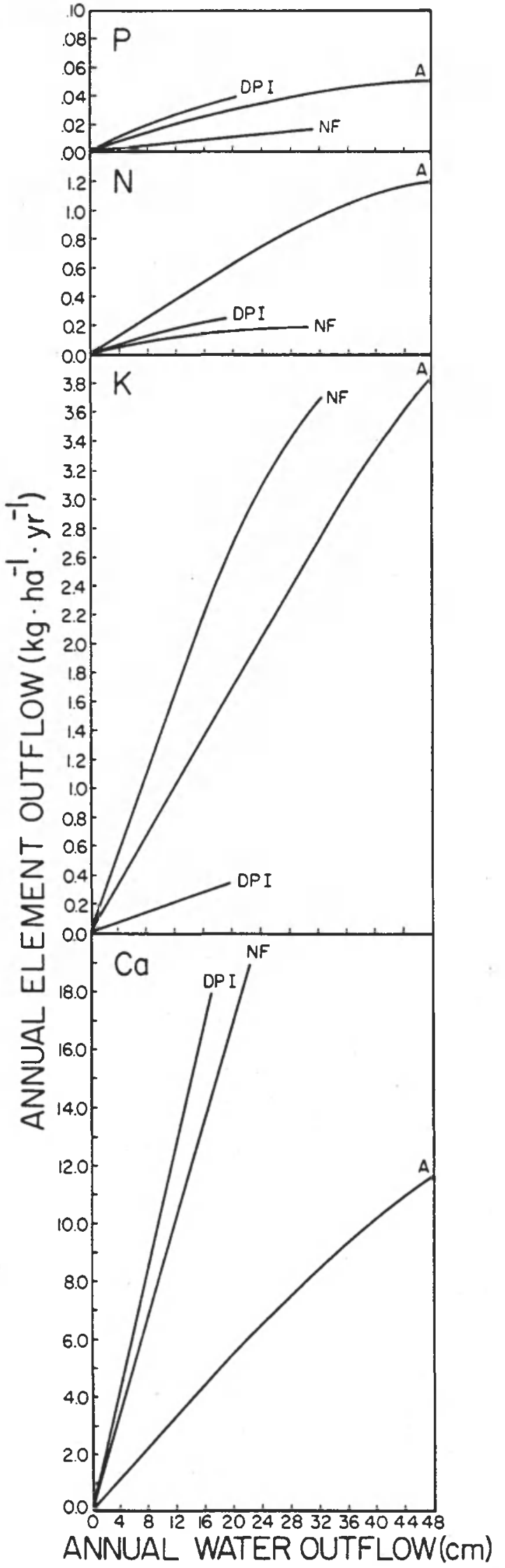

ment practices (Pfister 1981, Kaufmann et al. 1982). Changes in root distribution (Douglass 1967) or snow distribution (Gary 1974, Leaf and Alexander 1975) following timber harvest are other factors affecting water outflow.

If the outflow of water is reduced to zero in an intact forest, then nutrient outflow is reduced as well. Nutrient inputs continue, however, leading to a period (at least $1 \mathrm{yr}$ ) of improved nutrient availability for the biota. The importance of such nutrient enrichment episodes for decomposition, productivity, or pest resistance is unknown.

Even if water outflow does occur, there may not be a net loss of certain elements. Nitrogen, for example, is in short supply in western coniferous forests and appears to be assimilated whenever available (Fahey 1977, Gosz 1980, Sollins et al. 1980, Johnson et al. 1982). The same may occur for $K$ and P. Fahey (1977, 1983) found levels of inorganic $N$ and $K$ to be lower in surface runoff than in snow, which suggests that biotic immobilization occurs in the forest floor. $\mathrm{Nu}$ trient outflow is affected both by immobilization processes and by the quantity of water outflow, as well as by other factors that determine element concentrations in outflow water, such as anion availability (Johnson et al. 1982), the occurrence of soil frost (Lewis and Grant 1980), or organic $\mathrm{N}$ adsorption in the mineral soil (J. B. Yavitt and T. J. Fahey, personal observation). Further research may show how the major factors affecting element outfiow will vary depending on whether the outflow/input ratio is $<1$ or $>1$ (sensu Fig. 12).

Successional trends influence water and nutrient outflow from forests such as those we studied. For example, a common successional pattern is for aspen (Populus tremuloides Michx.) to give way to subalpine fir (Abies lasiocarpa [Hook.] Nutt.) and sometimes to lodgepole pine, i.e., a change from deciduous forest with less capacity for interception and VT to evergreen forest where VT and interception are greater. A reduction in outflow is predictable (Jaynes 1978), as has been observed by a number of investigators working in other areas (Urie 1967, Ayer 1968, Rutter 1968, Swank and Douglass 1974). Another successional pattern is for Engelmann spruce (Picea engelmannii Parry ex Engelm.) and subalpine fir to replace lodgepole pine. Although this change could lead to increased leaf area (Kaufmann et al. 1982), the effects on outflow, if any, are not known.

The major perturbations to lodgepole pine forests in our area are fire, timber harvest, and outbreaks of the mountain pine beetle. Any one of these may cause a reduction in leaf area, thereby increasing water outflow,

FIG. 11. Simulated annual outflow of $\mathrm{N}, \mathrm{P}, \mathrm{K}$, and $\mathrm{Ca}$ in relation to total water outflow from three contrasting stands (Albany, Nash Fork, and Dry Park). 
but the loss of limiting nutrients should be much greater following fire because of volatilization, reduction in forest floor carbon, and the greater erodability of ash. Woodmansee and Innis (1973) studied the effects of fire and clearcutting on long-term $K$ availability and tree growth in lodgepole pine forests, and concluded that additional data are required before an accurate comparison is possible.

Our results are relevant to several hypotheses offered to explain the observed variation in nutrient conservation by ecosystems. Odum (1969) postulated that nutrient conservation increases as more species occupy an ecosystem through time, but species diversity is so low throughout the successional sere in Rocky Mountain coniferous forests that this factor probably is minor. Another hypothesis suggests that spring ephemerals serve to conserve nutrients in ecosystems at times when outflow is potentially high (Muller and Bormann 1976, Muller 1978, Blank et al. 1980). However, biotic immobilization and the VT of evergreen conifers dwarf the role of small herbaceous plants, which are, in fact,

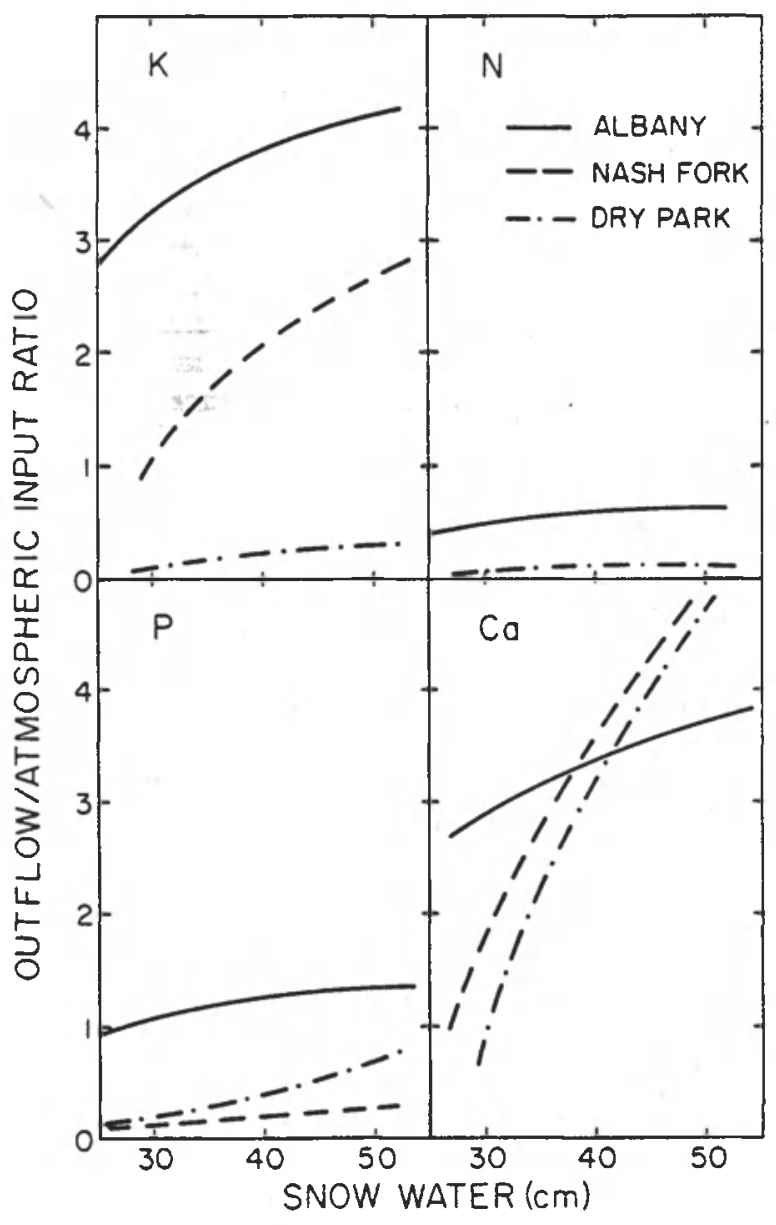

FIG. 12. Simulated outflow/atmospheric input ratios for $\mathrm{N}, \mathrm{P}, \mathrm{K}$, and $\mathrm{Ca}$ in relation to total snow water equivalent at three stands during 1980. Ratios $<1$ indicate nutrient accumulation. See Results: Element Input and Outflow.
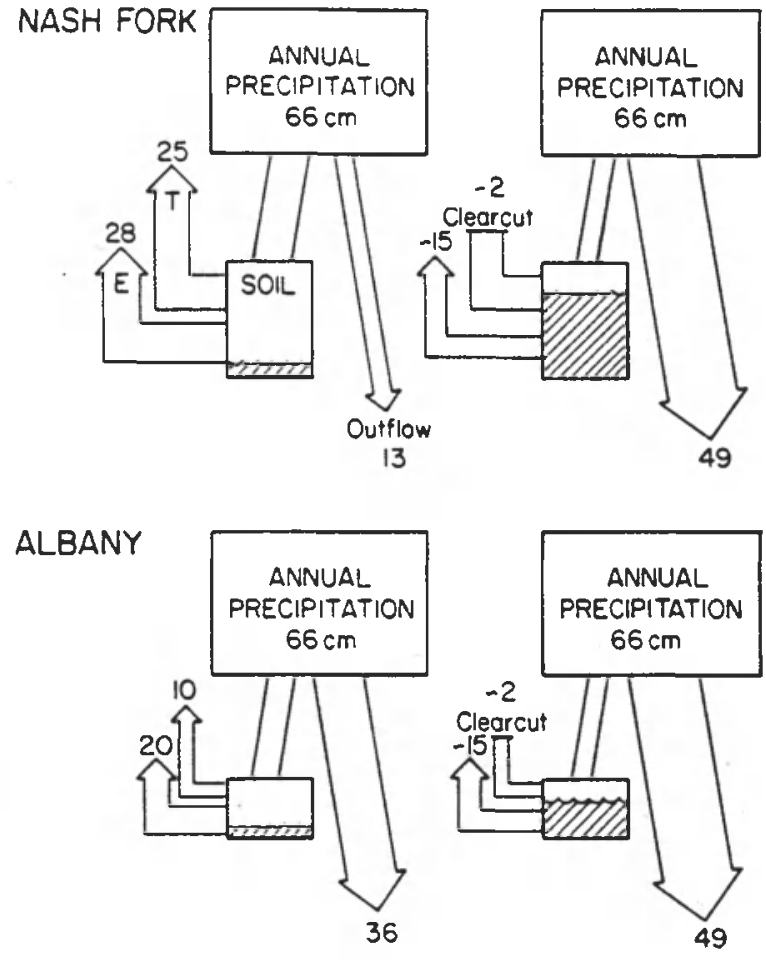

Fig. 13. Estimated water outflow from two contrasting stands before and after a simulated clear-cutting experiment. The annual hydrologic budget is depicted, with returns to the atmosphere being transpiration (T) and evaporation (E). The hatching in the soil compartment suggests differences in soil water storage capacity, with greater storage capacity before the clearcut (left) than in the 2nd yr after harvest (see Results: Simulation Studies).

almost entirely absent from upper montane coniferous forests in our region, being restricted to meadows and other openings.

Vitousek and Reiners (1975) suggested that the loss of limiting nutrients is reduced as long as biomass accumulation is occurring, but the ratios between carbon and various limiting nutrients such as $N$ and $P$ are so high in western coniferous forests (Gosz 1980) that microbial immobilization and formation of resistant humus may reduce nutrient outflow even in the absence of biomass accumulation (Fahey 1983). It seems doubtful that losses of limiting elements increase as succession progresses toward climax, especially considering that a catastrophic fire would probably occur before attainment of maximum biomass or climax (Romme and Knight 1981, Pearson 1982). For soilderived, nonlimiting elements, outflow depends more on soil water flux; stand features that minimize water outflow will also limit element outflow.

Our research leads us to conclude that, given a certain amount of snow water in mature lodgepole pine forests, variation in nutrient retention (or outflow) is more dependent on the development of maximum LAI (and root area) than on biomass accumulation, higher 
species diversity, or the presence of spring ephemerals. With the increase in LAI there is the potential for more VT, as discussed previously, in addition to more summer transpiration which dries the soil and thereby raises the storage capacity for water. Biomass may continue to accumulate long after maximum LAI is reached, but with little effect on the quantity of water and nutrient outflow. Similarly, a gradual decline in biomass (as in a degrading ecosystem) may not lead to increased outflow unless evergreen LAI is reduced also. Miller et al. (1979), Gosz (1980), and Johnson et al. (1982) discuss the various mechanisms for nutrient retention in coniferous forests. As suggested by Woodmansee (1978) for grasslands, net losses of limiting nutrients probably occur primarily in pulses after abiotic perturbations. Fire could be the most significant abiotic perturbation in lodgepole pine forest, though Lewis and Grant (1980) present data which suggest that frozen soils during low snowfall years could interfere with biotic immobilization and cause increased outflow of limiting elements.

\section{ACKNOWLEDGMENTS}

We are especially grateful to the following individuals for assistance, often under rigorous field conditions: Russell Campbell, Thomas R. Clarke, Gregory D. Joyce, Janice Marshall, Geoffrey McNaughton, John A. Pearson, Gregory Watson, Joseph B. Yavitt, and Donald R. Young. Larry Munn helped with soil classification, C. P. P. Reid and W. K. Smith assisted in the development of our physiological research, and Thomas R. Wentworth assisted generously with the implementation of H2OTRANS while D. H. Knight was on sabbatical at North Carolina State University (1979-1980). W. $H$. Schlesinger and two anonymous reviewers made helpful comments on the manuscript.

This research has been supported with grants from the $\mathrm{Na}$ tional Science Foundation (DEB 78-05-311, DEB 80-11024, DEB 81-13546), the Wyoming Water Research Center, and the United States Department of Interior (Office of Water Research and Technology).

\section{Literature Cited}

Alexander, R. R., and R. K. Watkins. 1977. The Fraser Experimental Forest, Colorado. United States Forest Service General Technical Report RM-40.

Ayer, G. R. 1968. Reforestation with conifers-its effect on streamflow in central New York. Water Resources Bulletin 4(2): 13-24.

Beardsell, M. F., P. G. Jarvis, and B. Davidson. 1972. A null-balance diffusion porometer suitable for use with leaves of many shapes. Joumal of Applied Ecology 9:677-690.

Bethlahmy, N. 1974. More streamflow after a bark beetle epidemic. Joumal of Hydrology 23:185-189.

Black, T. A., and D. L. Spittlehouse. 1981. Modelling the water balance for watershed management. Pages 117-129 in D. M. Baumgartner, editor. Interior west watershed management. Washington State University (Cooperative Extension), Pullman. Washington, USA.

Blake. G. R. 1965. Bulk density. Pages 374-390 in C. A. Black, editor. Methods of soil analysis (Part 1). American Society of Agronomy, Madison, Wisconsin, USA.

Blank, J. L., R. K. Olson, and P. M. Vitousek. 1980. Nutrient uptake by a diverse spring ephemeral community. Oecologia (Berlin) 47:96-98.

Bormann, F. H., G. E. Likens, and J. S. Eaton. 1969. Biotic regulation of particulate and solution losses from a forest ecosystem. BioScience 19:600-6 I0.

Cole, D. W., and M. Rapp. 1981. Elemental cycling in forest ecosystems. Pages 341-409 in D. E. Reichle, editor. Dynamic properties of forest ecosystems. Cambridge University Press, New York, New York, USA.

Dahms, W. G. 1971. Growth and soil moisture in thinned lodgepole pine. United States Forest Service Research Paper PNW-127.

Dietrich, T. L., and J. R. Meiman. 1974. Hydrologic effects of patchcutting of lodgepole pine. Hydrology Paper 66, Colorado State University, Fort Collins, Colorado, USA.

Douglass, J. E. 1967. Effects of species and arrangement of forest on evapotranspiration. Pages $451-460$ in W. E. Sopper and H. W. Lull, editors. International Symposium on Forest Hydrology. Pergamon. New York, New York, USA.

Fahey, T. J. 1977. Changes in nutrient content of snow water during outflow from Rocky Mountain coniferous forests. Oikos 32:422-428.

. 1979. The effect of night frost on transpiration of Pinus contorta ssp. latifolia. Oecologia Plantarum 14:483490.

1983. Nutrient dynamics of aboveground detritus in lodgepole pine (Pinus contorta ssp. latifolia) ecosystems, southeastern Wyoming. Ecological Monographs 53:51-72.

Fahey, T. J., and D. R. Young. 1984. Soil and xylem water potential and soil water content in contrasting Pinus contorta ecosystems, southeastern Wyoming. USA. Oecologia (Berlin) 61:346-351.

Federer, C. A. 1979. A soil-plant-atmosphere model for transpiration and availability of soil water. Water Resources Research 15:555-56?.

Fetcher, N. 1976. Patterns of leaf resistance to lodgepole pine transpiration in Wyoming. Ecology 57:339-345.

Gardner, W. H. 1965. Water content. Pages 82-127 in C. A. Black, editor. Methods of soil analysis (Part 1). American Society of Agronomy, Madison, Wisconsin, USA.

Gary, H. L. 1974. Snow accumulation and melt as influenced by a small clearing in a lodgepole pine forest. Water Resources Research 10:345-353.

Golterman, H. L., R. S. Clymo. and M. A. M. Ohnstad. 1978. Methods for physical and chemical analysis of fresh waters. Second edition. Blackwell, Oxford, England.

Gorham, E., P. M. Vitousek, and W. A. Reiners. 1979. The regulation of chemical budgets over the course of terrestrial ecosystem succession. Annual Review of Ecology and Systematics 10:53-84.

Gosz, J. R. 1980. Nitrogen cycling in coniferous ecosystems. In F. E. Clark and T. Rosswall, editors. Terrestrial nitrogen cycles. Ecological Bulletins-NFR 33:405-426.

Grier, C. C., and S. W. Running. 1977. Leaf area of mature northwestern coniferous forests: relation to site water balance. Ecology 58:893-899.

Halldin, S., editor. 1979. Comparison of forest water and energy exchange models. Intemational Society for Ecological Modelling, Copenhagen. Denmark.

Hart, G. E., N. V. DeByle, and R. W. Hennes. 1981. Slash treatment after clearcutting lodgepole pine affects nutrients in soil water. Journal of Forestry 79:446-450.

Jackson, M. L. 1958. Soil chemical analysis. Prentice-Hall, Englewood Cliffs, New Jersey. USA.

Jaynes, R. A. 1978. A hydrologic model of aspen-conifer succession in the Western United States. United States Forest Service Research Paper INT-213.

Johnson. D. W., D. W. Cole. C. S. Bledsoe. K. Cromack, R. L. Edmonds, S. P. Gessel. C. C. Grier, B. N. Richards, and K. A. Vogt. 1982. Nutrient cycling in forests of the Pacific Northwest. Pages 186-232 in R. L. Edmonds, editor. Analysis of coniferous forest ecosystems in the western United States. United States/International Biological Program Syn- 
thesis Series 14, Hutchinson Ross, Stroudsburg, Pennsylvania, USA.

Johnston, R.S. 1975. Soil water depletion by lodgepole pine on glacial till. United States Forest Service Research Note INT-199.

Johnston, R. S., and R. D. Doty. 1972. Description and hydrologic analysis of two small watersheds in Utah's Wasatch Mountains. United States Forest Service Research Paper INT-127.

Kaufmann, M. R. 1982. Evaluation of season, temperature and water stress effects on stomata using a leaf conductance model. Plant Physiology 69:1023-1026.

Kaufmann, M. R., C. B. Edminster, and C. A. Troendle. 1982. Leaf area determinations for subalpine tree species in the Central Rocky Mountains. United States Forest Service Research Paper RM-238.

Kaufmann, M. R., and C. A. Troendle. 1981. The relationship of leaf area and foliage biomass to sapwood conducting area in four subalpine forest trees. Forest Science 27:477482.

Knight, D. H., T. J. Fahey, S. W. Running, A. T. Harrison, and L. L. Wallace. 1981. Transpiration from a 90-year. old lodgepole pine forest estimated with whole-tree potometers. Ecology 62:717-726.

Leaf, C. F. 1975. Watershed management in the Rocky Mountain subalpine zone: the status of our knowledge. United States Forest Service Research Paper RM-137.

Leaf, C. F., and R. R. Alexander. 1975. Simulating timber yields and hydrologic impacts resulting from timber harvest on subalpine watersheds. United States Forest Service Research Paper RM-133.

Lewis, W. M., Jr., and M. C. Grant. 1979. Changes in the output of ions from a watershed as a result of the acidification of precipitation. Ecology 60:1093-1097.

Lewis, W. M., Jr., and M. C. Grant. 1980. Relationships between snow cover and winter losses of dissolved substances from a mountain watershed. Arctic and Alpine Research 12:11-17.

Likens, G. E.,F. H. Bormann, R. S. Pierce. J. S. Eaton, and N. M. Johnson. 1977. Biogeochemistry of a forested ecosystem. Springer-Verlag, New York, New York, USA.

Lohammar, T., S. Larasson, S. Linder, and S. O. Falk. 1980. FAST-Simulation models of gaseous exchange in Scots pine. In T. Persson, editor. Structure and function of northern coniferous forests. Ecological Bulletins-NFR 32:505-523.

Love, L. D. 1955 . The effect on streamflow of the killing of spruce and pine by the Engelmann spruce beetle. Transactions of the American Geophysical Union 36:113-118.

Luxmoore, R. J., D. D. Huff, R. K. McConathy, and B. E. Dinger. 1978. Some measured and simulated plant water relations of yellow-poplar. Forest Science 24(3):327-34l.

Luxmoore, R. J., J. L. Stolzy, and J. T. Holdeman. 1981. Sensitivity of a soil-plant-atmosphere model to changes in air temperature, dew point temperature and solar radiation. Agricultural Meteorology 23:1 15-129.

McColl, J. G. 1973. Environmental factors influencing ion transport in a Douglas-fir forest soil in western Washington. Journal of Ecology 61:71-83.

Miller, H. G., J. M. Cooper, J. D. Miller, and O. Pauline. 1979. Nutrient cycles in pine and their adaptation to poor soils. Canadian Journal of Forest Research 9:19-26.

Moir, W. H., and R. Francis. 1972. Foliage biomass and surface area in three Pinus contorta plots in Colorado. Forest Science 18:41-45.

Muller. R. N. 1978. The phenology, growth and ecosystem dynamics of Erythronium americanum in the northern hardwood forest. Ecological Monographs 48:1-20.

Muller. R. N., and F. H. Bormann. 1976. Role of Erythronium americanum $\mathrm{Ker}$. in energy flow and nutrient dynamics of a northern hardwood forest ecosystem. Science 193: $1126-1128$.
Odum, E. P. 1969. The strategy of ecosystem development. Science 164:262-270.

Owston. P. W., J. L. Smith, and H. G. Halverson. 1972. Seasonal water movement in tree stems. Forest Science 18: 266-272.

Parizek, R. R., and B. E. Lane. 1970. Soil water sampling using pan and deep pressure-vacuum lysimeters. Journal of Hydrology 11:1-2l.

Pearson, J. A. 1982. Biomass distribution and ecosystem development in lodgepole pine forests of the Medicine Bow Mountains, Wyoming. Dissertation. University of Wyoming, Laramie, Wyoming, USA.

Pearson, J. A., T. J. Fahey, and D. H. Knight. 1984. Biomass and leaf area in contrasting lodgepole pine forests. Canadian Journal of Forest Research 14:259-265.

Persson. T., editor. 1980. Structure and function of northern coniferous forests. Ecological Bulletins-NFR 32.

Pfister, R. D. 1981. Habitat type classification for managing western watersheds. Pages 59-67 in D. M. Baumgartner, editor. Interior west watershed management. Washington State University (Cooperative Extension), Pullman, Washington, USA.

Rawitz, E., E. T. Engman, and G. D. Cline. 1970. Use of the mass balance method for examining the role of soils in controlling watershed performance. Water Resources Research 6:1115-1123.

Reynolds, J. F., and D. H. Knight. 1973. The magnitude of snow-melt and rainfall interception by litter in lodgepole pine and spruce-fir forests in Wyoming. Northwest Science 47:50-60.

Romme. W. H., and D. H. Knight. 1981. Fire frequency and subalpine forest succession along a topographic gradient in Wyoming. Ecology 62:319-326.

Running. S. W. 1980a. Environmental and physiological control of water flux through Pinus contorta. Canadian Journal of Forest Research 10:82-91.

- $1980 \mathrm{~b}$. Field estimates of root and xylem resistances in Pinus contorta using root excision. Journal of Experimental Botany 31:555-569.

- $1980 \mathrm{c}$. Relating plant capacitance to the water relations of Pinus contorta. Forest Ecology and Management 2:237-252.

1984. Documentation and preliminary validation of H2OTRANS and DAYTRANS, two models for predicting transpiration and water stress in western coniferous forests. United States Forest Service Research Paper RM252.

Running, S. W., D. H. Knight, and T. J. Fahey. 1983. Description and application of H2OTRANS, a stand level hydrologic model for western coniferous forests. Pages 489495 in W. K. Lauenroth. G. V. Skogerboe, and M. Flug, editors. Analysis of ecological systems: state-of-the-art in ecological modelling. Elsevier Scientific Publishing, New York, New York, USA.

Rutter, A. J. 1968. Water consumption by forests. Pages 23-84 in T. T. Kozlowski, editor. Plant water consumption and response. Water deficits and plant growth. Volume 2. Academic Press. New York, New York, USA.

Rutter, A. J., D. A. Kershaw, P. C. Robins, and A. J. Morton. 1972. A predictive model of rainfall interception in forests, I. Derivation of the model from observations in a plantation of Corsican pine. Agricultural Meteorology 9:367-384.

Schlesinger, W. H.. and W. A. Reiners. 1974. Deposition of water and cations on artificial foliar collectors in fir krummholz of New England mountains. Ecology 55:378386.

Shaffer. K. A., D. D. Fritton. and D. E. Baker. 1979. Drainage water sampling in a wet, dual-pore soil system. Journal of Environmental Quality 8:241-246.

Sinclair. T. R., C. E. Murphy. and K. R. Knoert. 1976. Development and evaluation of simplified models for simu- 
lating canopy photosynthesis and transpiration. Journal of Applied Ecology 13:813-829.

Sollins, P., R. A. Goldstein, J. B. Mankin, C. E. Murphy, and G. L. Swartzman. 1981. Analysis of forest growth and water balance using complex ecosystem models. Pages 537 565 in D. E. Reichle, editor. Dynamic properties of forest ecosystems. International Biological Program Volume 23, Cambridge University Press, Cambridge, England.

Sollins, P., C. C. Grier, F. M. McCorison, K. Cromack, Jr., and R. Fogel. 1980. The internal element cycles of an oldgrowth Douglas-fir stand in western Oregon. Ecological Monographs 50:26!-285.

Stark, N. M. 1972. Nutrient cycling pathways and litter fungi. BioScience 22:355-360.

- 1979. Nutrient losses from timber harvesting in a larch/Douglas fir forest. United States Forest Service Research Paper INT-231.

Stottlemeyer, J. R., and C. W. Ralston. 1970. Nutrient balance relationships for watersheds of the Fraser Experimental Forest. Pages 359-383 in C. T. Youngberg and C. B. Davey, editors. Tree growth and forest soils. Oregon State University Press, Corvallis, Oregon, USA.

Swank, W. T., and J. E. Douglass. 1974. Streamflow greatly reduced by converting deciduous hardwoods to pine. Science 185:857-859.

Swanson, R. H. 1967. Seasonal course of transpiration of lodgepole pine and engelmann spruce. Pages 419-434 in W. E. Sopper and H. E. W. Lull, editors. International symposium on forest hydrology. Pergamon, New York, New York, USA.

Tan, C. S., T. A. Black, and J. U. Nnyamah. 1978. A simple diffusion model of transpiration applied to a thinned Douglas-fir stand. Ecology 59:1221-1229.

Urie, D. H. 1967. Influence of forest cover on ground water recharge, timing and use. Pages 313-323 in W. E. Sopper and $\mathrm{H}$. W. Lull, editors. International symposium on forest hydrology. Pergamon, New York, New York, USA.

van Bavel, C. H. M. 1958. Measurement of soil moisture content by the neutron method. United States Department of Agriculture Agricultural Research Service ARS Series 41, Number 24.

Vitousek, P. M., and W. A. Reiners. 1975. Ecosystem succession and nutrient retention: a hypothesis. BioScience 25:376-381.

Waggoner, P. E., and N.C. Turner. 1971. Transpiration and its control by stomata in a pine forest. Bulletin Number 726, Connecticut Agricultural Experiment Station, New Haven, Connecticut, USA.

Waring, R. H., W. H. Emmingham, H. L. Gholz, and C. C. Grier. 1978. Variation in maximum leaf area of coniferous forests in Oregon and its ecological significance. Forest Science 24:131-140.

Waring, R. H., J. J. Rogers, and W. Swank. 1981. Water relations and hydrologic cycles. Pages 205-264 in D. E. Reichle, editor. Dynamic properties of forest ecosystems. International Biological Program Volume 23, Cambridge University Press, Cambridge, England.

Waring, R. H., and S. W. Running. 1976. Water uptake, storage and transpiration by conifers: a physiological model. Pages 189-202 in O. L. Lange, E. D. Schulze, and L. Kappen, editors. Water and plant life: problems and modern approaches. Ecological Studies Volume 19. SpringerVerlag, Berlin, Germany.

White, C. S., and J. R. Gosz. 1981. Organic nitrogen interference with automated ammonium analyses. Canadian Journal of Forest Research 11:739-741.

White, E., R. S. Starkey, and M. J. Saunders. 1971. An assessment of the relative importance of several chemical sources to the waters of a small upland catchment. Journal of Applied Ecology 8:743-749.

Woodmansee, R. G. 1978. Additions and losses of nitrogen in grassland ecosystems. BioScience 28:448-453.

Woodmansee, R. G., and G. S. Innis. 1973. A simulation model of forest growth and nutrient cycling. Proceedings of the Summer Computer Simulation Conference 2:697721 . 